\title{
Marine shell hoard from the Late Neolithic site of Čepin-Ovčara (Slavonia, Croatia)
}

\author{
Boban Tripković ${ }^{1}$, Vesna Dimitrijević 2 and Dragana Rajković3 \\ 1 Department of Archaeology, Faculty of Philosophy, University of Belgrade, RS \\ btripkov@f.bg.ac.rs \\ 2 Laboratory for Bioarchaeology, Department of Archaeology, Faculty of Philosophy, University of Belgrade, RS \\ vdimitri@f.bg.ac.rs \\ 3 Museum of Slavonia in Osijek, HR \\ dragana.rajkovic@mso.hr
}

\begin{abstract}
The focus of this paper is the ornament hoard from the Sopot culture site of Čepin-Ovčara in eastern Slavonia (the Republic of Croatia). The hoard contained pendants and beads made of shells of marine clam Spondylus gaederopus and scaphopod Antalis vulgaris. The paper analyses the context and use wear of the objects in the hoard. The results form a basis for: the reconstruction of the role of some of the items and the ways in which they were worn; the premise that the dynamics and mechanisms of acquisition of ornaments made of the two Mediterranean mollusc species could have differed; and the identification of a cross-cultural pattern of deposition of ornament hoards.
\end{abstract}

IZVLEČEK - V članku se osredotočamo na zakladno najdbo z nakitom iz časa sopotske kulture na najdišč Čepin-Ovčara v vzhodni Slavoniji (Republika Hrvaška). Depo vsebuje obeske in jagode, izdelane iz lupin morskih školjk vrste Spondylus gaederopus in polžkov vrste Antalis vulgaris. V članku analiziramo kontekste in sledove uporabe teh izdelkov. Rezultati nam nudijo osnovo za: rekonstrukcijo vloge nekaterih izdelkov in načinov nošenja nakita; premiso o različnih dinamikah in mehanizmih pridobivanja okrasov iz dveh sredozemskih vrst mehkužcev; in za prepoznavanje medkulturnih vzorcev odlaganja zakladnih najdb z nakitom.

KEY WORDS - Late Neolithic; Sopot culture; marine shell hoard; Spondylus; Antalis

\section{Introduction}

Objects made of marine animal shell discovered at sites on the European mainland are important not only because of their basic and symbolic function; they are also evidence of contacts and exchange with communities that lived by the sea. The importance of these objects is reinforced through their exotic origin, their often highly meticulous manufacture, as well as their deposition in graves and hoards (Chapman 2000; Müller 1997). However, the distribution and ubiquity of such ornaments across the European continent have been considered primarily for objects made of Spondylus shell. In contrast, there are no sufficient data on areas and periods in which ornaments made from shell of other marine animals occur.
The distribution map of spondylus items (as shown in Müller 1997; Dimitrijević, Tripković 2006; Todorova 1995; Willms 1985; Windler 2013) shows that the territory of eastern Slavonia (the Republic of Croatia), bordered by the rivers Sava, Drava, and Danube, lies in the centre of an area in which the ornaments have been sporadically documented since the beginning of the 20th century (Brunšmid 1902; Dimitrijevic 1968). The number of sites investigated in the region has significantly increased in the last decades, thanks primarily to rescue excavations that preceded the construction of major roads (see Balen, Hršak and Šošić-Klindžić 2014). Ornaments made from Spondylus and other marine species were found in graves and settlements from different phases of 
the Neolithic. However, a single ornament hoard was discovered, at the Late Neolithic Čepin-0včara site, and this is the focus of this paper.

\section{Method and terminology}

For the taxonomic identification of shells in the Čepin hoard, preserved shell morphology was used according to the criteria provided in Walter Fischer et alii (1987) and Raymond Moore (1969) as well as the online source Seashells collections (Caro 19972011). The taxonomic nomenclature follows CLEMAM - Check List of European Marine Mollusca (Le Renard 1994).

Besides the scientific names of species, and also of higher-ranking taxa from which the shells used for the ornament manufacture derived (Spondylus gaederopus, Spondylus, Antalis vulgaris, Scaphopoda), common names are also used here. These are the names most often used by archaeologists to denote these kinds of objects, regardless of whether a taxonomic identification has been carried out or not: 'spondylus', for objects made of shell of Spondylus gaederopus and/or other species, and 'dentalium', for objects made of scaphopoda shells. The scientific names are given in italics, as is customary, and hence differentiated from the common names.

The morphological characteristics of the shells were observed with the naked eye, whereas the structure of the shell visible in cross-section was examined under a binocular magnifier with $\mathrm{x} 45$ magnification. The criteria (stated in Dimitrijevic, Tripkovic 2006) were applied in order to exclude the possible use of fossil shells in the manufacture of the ornaments. The dimensions of the objects were taken with a calliper to $1 \mathrm{~mm}$ precision. The weight was measured on digital scales to $0.1 \mathrm{~g}$ precision.

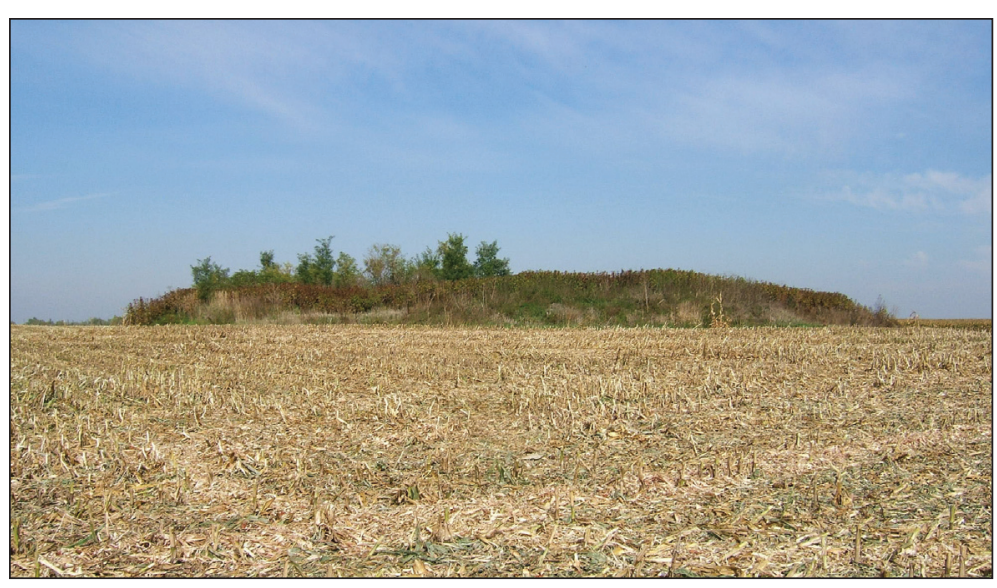

Fig. 1. The site of Čepin-Ovčara (photo Museum of Slavonia).
The reconstruction of the function, i.e. the way in which shell items were worn, was performed through a macroscopic analysis of the incisions created by the strings on which individual pieces of ornament were originally placed. Traces of accidental damage on the objects resulting from their use were also observed microscopically by $\mathrm{x} 45$ binocular magnifier.

\section{The Čepin-0včara site}

Čepin is a village settlement located in a micro-region within the Drava-Danube lowlands of the eastern Croatian plain, $12 \mathrm{~km}$ from the town of Osijek. The 0včara archaeological site is situated on the outskirts of Čepin, immediately adjacent to the road to Djakovo, on a prominent hillock extending in the northwest-southeast direction (Fig. 1). The immediate surroundings of Čepin are in the area of an alluvial plain comprised of different landforms - the Drava river terrace and the Vuka river valley. This is swampy land interspersed with loess ridges (locally known as 'praporne grede'), in the form of elongated areas of high ground that remain dry even in seasons of maximum water table. This land is now used for intensive agricultural production, and the region is characterised by long-lasting continuous habitation (Roglić 2006.134).

From 1997 to 2006, systematic archaeological investigations of a $300 \mathrm{~m}^{2}$ area were carried out by Jasna Šmić. A late medieval building (from the $13^{\text {th }}$ to the $14^{\text {th }}$ century), an early medieval cemetery of the Bjelo Brdo culture, and a Neolithic settlement of the Sopot culture were discovered (Šimić 2006a. 10; $2007 b$. 41; Rajkovic 2014). The presence of a medieval building furnished with an apse affected the planning of the fieldwork, as the walls of the building determined the shapes of the excavation trenches. Thus each room of the building had a separate excavation trench. The remains of the Neolithic settlement include an array of diverse habitation elements, such as semi-subterranean structures, traces of above-ground architecture, postholes, pits and wells. Due to the disturbed stratigraphy and numerous burial pits, the relationships between individual stratigraphic units could not be clearly defined, and the excavation layers in different trenches could not be interconnected; this makes the entire interpretation of the sites' stratigraphy very difficult. 
Based on observations made so far, the Neolithic settlement comprises several building horizons (Šimić 2006a; 2006b; Rajković 2014). In the earliest horizon of Neolithic occupation, variously shaped pits made for different purposes were uncovered, as well as part of a large, irregularly shaped dug-out structure with traces of thick posts, which has been interpreted as a pit-house ( $\breve{S} i$ mić 2006a; 2006b). These features were dug into the virgin soil. The earliest settlement phase was overlain with a layer consisting of the remains of rectangular above-ground buildings oriented northwest-southeast (Fig. 2). A total of 18 floors were detected, generally constructed from

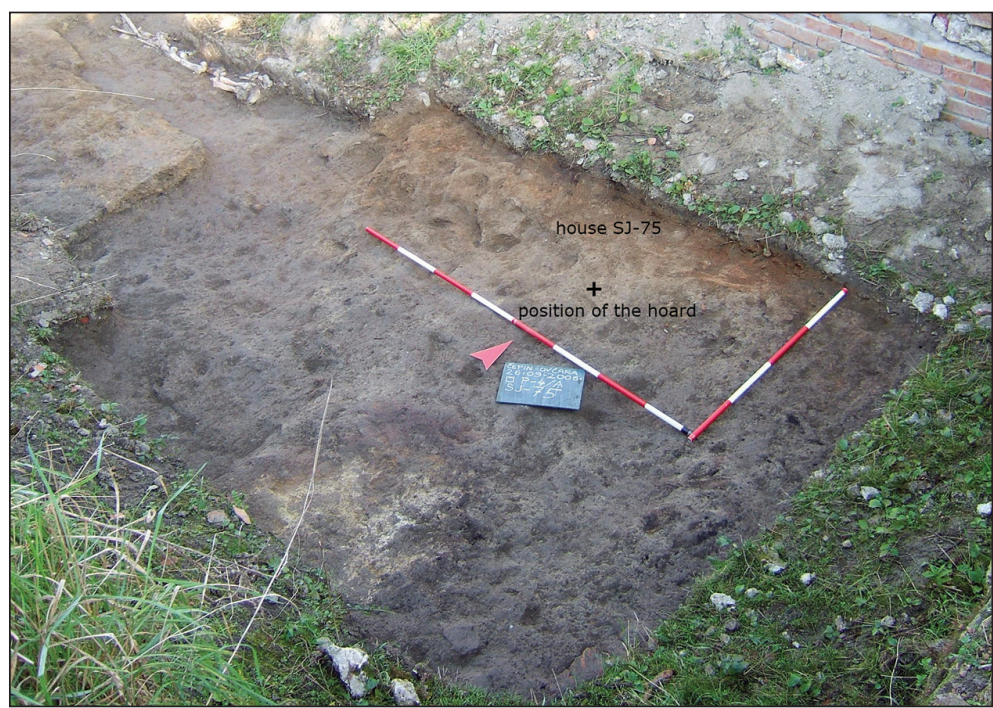

Fig.2. Čepin-Ovčara, sector 4: building SJ-75 (photo Museum of Slavonia). baked soil placed on top of a wooden construction sitting on a layer of hard-packed clay. In some trenches, more floor levels were noticed, probably pertaining to different building phases (Šimić 2006b. 41). Due to the small size of the areas excavated within the walls of the Late Medieval building, no single above-ground Late Neolithic structure could be investigated in its entirety, which constrains a wider interpretation of the excavated features. the middle and later phases of the Sopot culture, i.e. phases II and III according to Dimitrijević (Dimitrijević 1968.41, 48-49).

Four radiometric dates were obtained for the Neolithic occupation of the site (Tab. 1). The date Z-3750 on charcoal places the earliest investigated cultural layer of the site in the period from 5054 to $4730 \mathrm{cal}$ BC (at $95.4 \%$ probability). This horizon would cor-
A large quantity of diverse materials was recovered from the site. In addition to the usual products of pottery manufacture, one should mention a high number of animal bones, clay balls, spindle whirls made of potsherds, chipped stone, obsidian, and an anthropomorphic clay figurine (Šimić 2007b.13). The vessel types include pots of different outline decorated with modelled bands filled with fingerprints, biconical and conical bowls, cups with a foot, miniature vessels, and ceramic strainers. The ceramic ware is mostly grey and black, while some of the fragments are decorated with red paint. The typological characteristics of the pottery, stone and chipped stone from the Late Neolithic layer indicate

\begin{tabular}{|l|c|c|c|}
\hline $\begin{array}{l}\text { Laboratory } \\
\text { code }\end{array}$ & Sample & $\begin{array}{c}\text { Radiocarbon } \\
\text { age (BP) }\end{array}$ & Calibrated date \\
\hline Z-3750 & charcoal; & $6010 \pm 60$ & $68.2 \%$ probability \\
& cultural layer (Sj 62) & & $4986(68.2 \%) 4836 \mathrm{cal} \mathrm{BC}$ \\
& between houses & & $95.4 \%$ probability \\
& Sj 47 and Sj 60 & & $5054(93.7 \%) 4765 \mathrm{cal} \mathrm{BC}$ \\
& & & $4758(1.7 \%) 4730 \mathrm{cal} \mathrm{BC}$ \\
\hline Z-3751 & charcoal; & $5940 \pm 70$ & $68.2 \%$ probability \\
& layer Sj 69 & & $4902(14.2 \%) 4863 \mathrm{cal} \mathrm{BC}$ \\
& (ashy layer with & & $4856(54 \%) 4725 \mathrm{cal} \mathrm{BC}$ \\
& some charcoal) & & $95.4 \%$ probability \\
& & & $5006(94.6 \%) 4679 \mathrm{cal} \mathrm{BC}$ \\
& & & $4636(0.8 \%) 4619 \mathrm{cal} \mathrm{BC}$ \\
\hline Z-3264 & charcoal; & $5900 \pm 90$ & $68.2 \%$ probability \\
& semi-subterranean & & $4908(67.2 \%) 4684 \mathrm{cal} \mathrm{BC}$ \\
& structure Sj 28/29 & & $4630(1.0 \%) 4624 \mathrm{cal} \mathrm{BC}$ \\
& & & $95.4 \%$ probability \\
& & & $4996(95.4) \% 4547 \mathrm{cal} \mathrm{BC}$ \\
\hline Z-3263 & charcoal; & $5500 \pm 90$ & $68.2 \%$ probability \\
& floor of the house & & $4452(54.3 \%) 4314 \mathrm{cal} \mathrm{BC}$ \\
& Sj 16/17 & & $4301(13.9 \%) 4261 \mathrm{cal} \mathrm{BC}$ \\
& & & $95.4 \%$ probability \\
& & & $4537(87.5 \%) 4223 \mathrm{cal} \mathrm{BC}$ \\
& & & $4207(4.0 \%) 4159-4070 \mathrm{cal} \mathrm{BC}$ \\
& & & 4018 (0.1\%) $3998 \mathrm{cal} \mathrm{BC}$ \\
& & &
\end{tabular}

Tab. 1. Radiocarbon dates from Čepin-Ovčara. Dates were calibrated using OxCalv4.2.4 Bronk Ramsey (2013); r5; IntCal 13 atmospheric curve (Reimer et al. 2013). 
respond with the earlier part of the classical period of Sopot culture (between 5000 and $4500 / 4400 \mathrm{cal} \mathrm{BC}$, according to Balen, Čataj 2014; phases IB-III after Dimitrijević 1968). Somewhat later, but still during the classical period of Sopot culture, are the dates Z-3751 and Z-3264, which range between 5006 and $4619 \mathrm{cal} \mathrm{BC}$ and between 4996 and 4547 cal BC, respectively (at $95.4 \%$ probability). The latest date (Z-3263) for the settlement, obtained from charcoal recovered from the floor of an above-ground structure, indicates the period from 4537 to 4070 cal BC (at $95.4 \%$ probability). This range falls mostly within the Eneolithic sequence of Sopot culture (Balen, Čataj 2014) which so far has not been reported for the site. It is thus clear that the radiometric dates point to the continuity of the Neolithic settlement through several phases of development, but a stronger correlation between absolute and relative chronology is yet to be established.

\section{The marine shell hoard}

The hoard of objects made of sea shells was discovered in 2006 on the south side of a burnt house (sector P4, SJ-75), covered by its remains (Fig. 3ab). The remains of the structure derive from the final occupation horizon of the Late Neolithic settlement. The floor of the structure was not fully excavated, and one part of it extends into the north profile of the trench. The dimensions of the area of the exposed portion of the floor are $2.80 \times 0.70 \mathrm{~m}$. The floor consisted of $10-15 \mathrm{~cm}$ thick burnt soil, under which
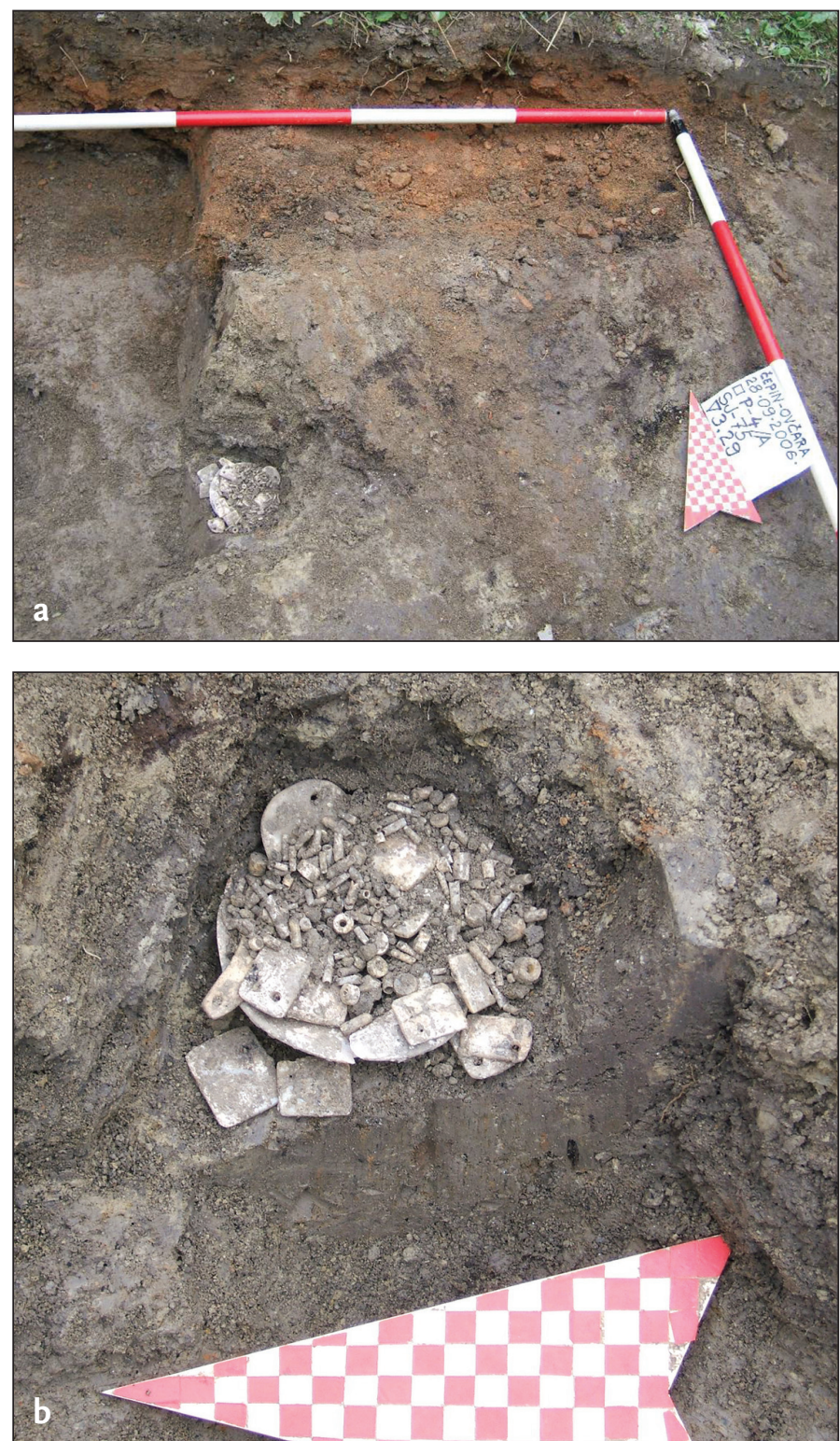

Fig. 3. Čepin-Ovčara, marine shell hoard: a broader context, b detail (photo Museum of Slavonia). was a layer of charred wood comprising the remains of a substructure assembled from planks placed on top of a layer of compact clay. The overall thickness of the floor was 30cm (Šimić 2007a.66-68; $2007 b$. 13). On the basis of the burnt remains, it can be assumed that this building was destroyed by fire, as was the case with other buildings at the site. The archaeological material found in the floor includes a fragment of a stone quern and another complete quern, a worked antler and a microlith; pottery was not recorded.

The hoard comprised 15 oval and trapezoidal pendants, one elongated pendant, 58 beads made of spondylus, and 386 tubular dentalium beads (Figs. $4-5)$. The total weight of the objects is $166 \mathrm{~g}$. The pendants and beads were deposited in the largest of the pendants, created from a whole valve of the clam (Šimić 2007b.13). The objects in the hoard probably formed three composite ornaments. The spondylus pendants each have two stringing holes, and it is assumed that they were parts of a single piece of adornment - a belt - while the spondylus beads were probably strung on a thread for one necklace, and the dentalium beads for another. In the text that follows, these composite decorative objects are described separately.

\section{The belt}

Fifteen objects made of spondylus shell, each fitted with two holes for stringing, can be interpreted as pendants or, as we prefer for this particular set, as 
segments of a single belt. The largest piece was created from a left valve, whereas the remaining 14 represent circular, oval and polygonal cut-outs from the shell. The morphological elements of the valve indicating the type of shell from which the pendants were made are preserved only on the largest of the segments, on the inner surface of the valve; the outer surface of the valve and the hinge line have been worked and significantly modified. The original natural ornamentation of the valve is not preserved. The valve margins were trimmed and rounded, and the hinge area smoothened and flattened so that there are no traces of the ligamental grooves or the hinge teeth. Based on the shape and size of the valve, as well as the appearance of the hinge mechanism and the position of the ligament, it can be concluded that the largest segment was from the left valve of a shell of the genus Spondylus; its dimensions suggest that it is Spondylus gaederopus. The valve is oval, and appears elongated in vertical crosssection. On the inside of the valve, the scar of a large adductor muscle and the pallial line are clearly visible. The preserved height of the valve is $85 \mathrm{~mm}$, and its preserved thickness, measured in the centre of the valve, is $6 \mathrm{~mm}$. Among the species of the genus Spondylus that occur in European seas (Clemam

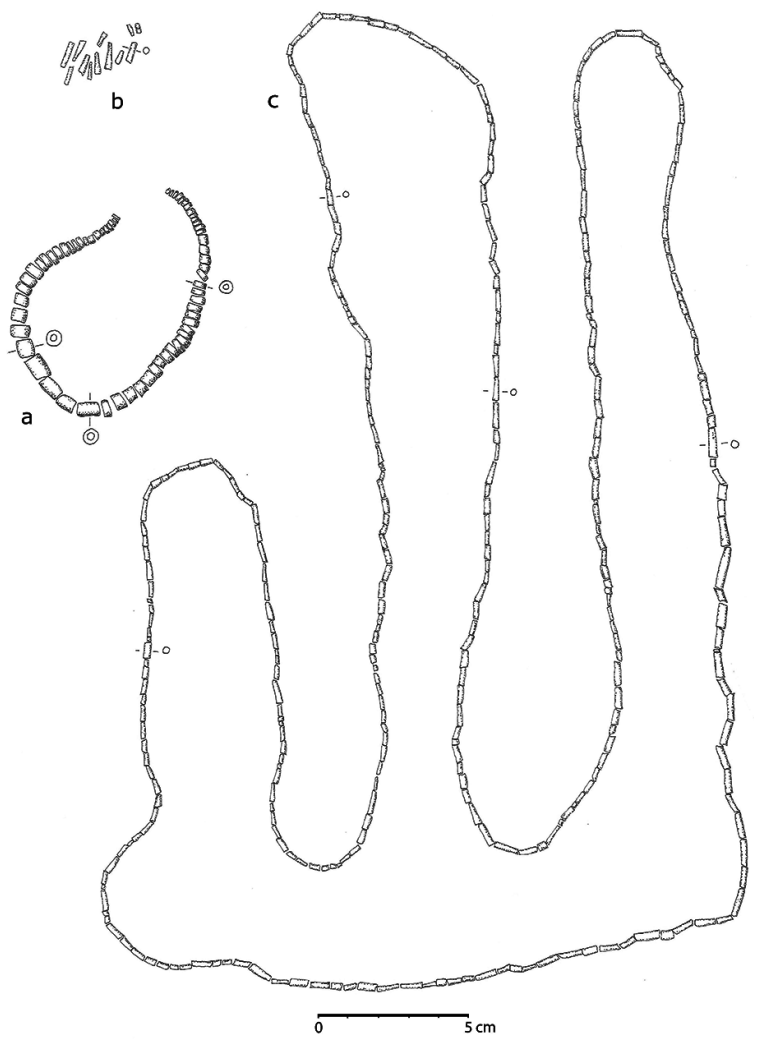

Fig. 5. Čepin-Ovčara hoard: a spondylus beads arranged in a string, b few loose dentalium beads, c dentalium beads arranged in a string (drawings by D. Radman).

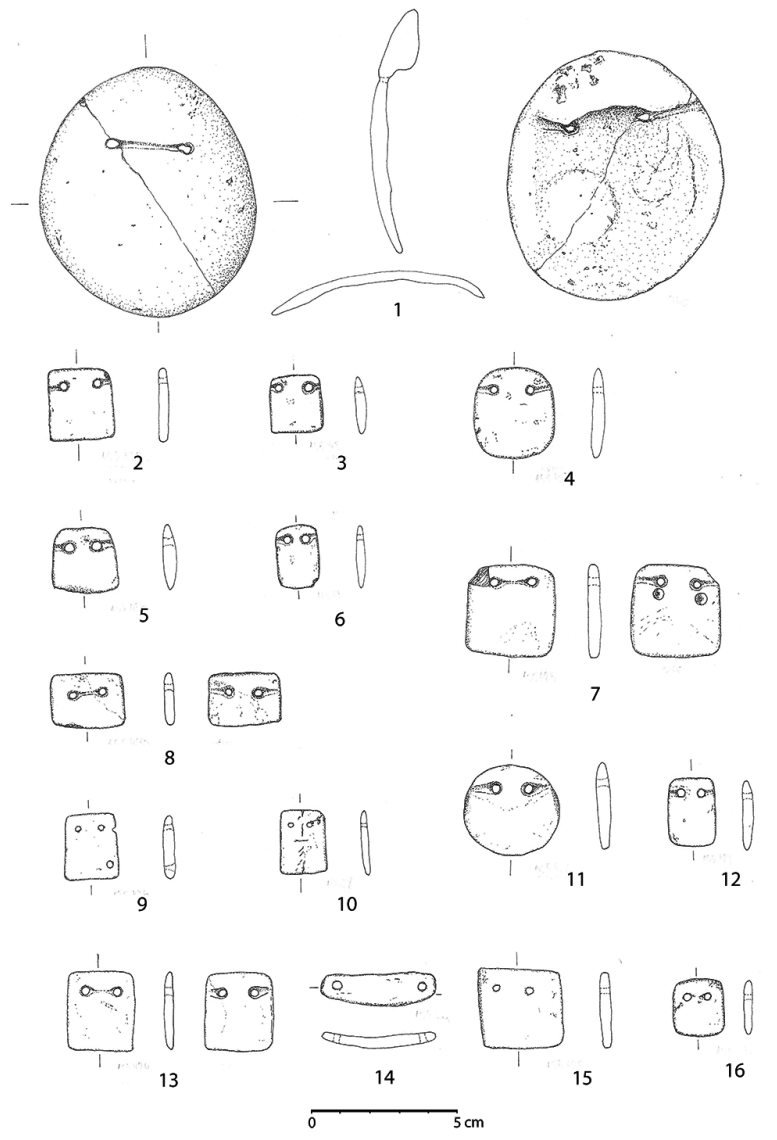

Fig. 4. Čepin-Ovčara hoard: spondylus pendants (drawings by D. Radman).

2014), only Spondylus gaederopus attains these dimensions. On the outer and inner surfaces of the valve the interior structure is visible in places, and is particularly clear in the area of the hinge. It is characterised by alternating transparent and opaque white laminae, i.e. growth lines whose frequency and curvature varies depending on the angle at which the valve is cut. The lines extend in the form of a wave of variable amplitude. The growth lines were also sporadically noticed in other segments (for example, segments No. 1 in Table 2, Fig. 8.c, and No. 14 , Fig $8 \mathrm{~b}$ ), along with a rare trace of the valve's morphology. For instance, in the central part of one item (Fig. 4.15, No. 15 in Table 2) there is a shallow depression remaining from the scar of the adductor muscle that was flattened out through polishing. In another one (Fig. 4.5, No. 8 in Table 2), in the area above the stringing holes there is a dimple, which is either from the scar of the adductor muscle or is an irregularity on the inner surface of the valve.

The largest pendant or belt segment is ovoid in outline, and has one smooth convex surface which can be defined as the outer face, which was created by shaping the outer surface of the valve (Figs. 4.1; 6). 
There are two holes near the upper margin set $20 \mathrm{~mm}$ apart. The impressions of the string are visible in the area between the holes. The opposite, inner face of the object, which is the inner surface of the valve, was most probably turned towards the body. The hinge was flattened through polishing; its upper parts, initially rectangular, were trimmed to obtain the rounded, ovate outline of the whole object. The remainder of the inner face consists of the concave inner surface of the valve whose central part was not worked, and thus it preserves the scar of the adductor muscle and the pallial line. The flattened hinge and the trimmed, flattened and rounded edges of the valve are all in the same plane, i.e. they lean almost perfectly against the background. It is very probable that when the pendant was worn, its inner side faced the body and the convex side was visible, because if the pendant had been turned the other way, it would have been uncomfortable to wear it, given its large size, and would also result in deep incisions made by the string. On the inner surface of the pendant, the holes for stringing are located immediately below the hinge. The impressions of the string extend horizontally from the holes towards the lateral sides of the object, and are tilted slightly upwards. It is thus clear that this is not a pendant or an amulet worn around the neck, since if it were, then the use wear on the inner surface would extend vertically from each of the holes and upwards, rather than horizontally sideways.

For the remaining 14 pendants, i.e. belt segments, it can also be assumed which side was turned toward the body and which side was readily seen. These pendants are shaped as small plates with an oval, trapezoid or rhomboid outline (Fig. 4.2-13, 15-16). In most of them, one side is slightly convex while the other is flat. Usually, the slightly convex surface looks glossier, i.e. it appears more polished than the flat side. Also, in most pendants, this better polished surface is covered with fine scratches oriented in various directions, probably due to wear when the pendants were used. There are fewer of these marks on the other, flat side.

The imprints of the string in the area between the holes are in all pieces located on the convex, better polished surface; the string marks that extend from the holes towards the lateral sides of the objects are visible on their flat surface. Similar to the largest of the pendants, here it can also be assumed that the slightly convex, smooth surface was the front side, while the less carefully worked surface was the back and was turned towards the body. The pendants
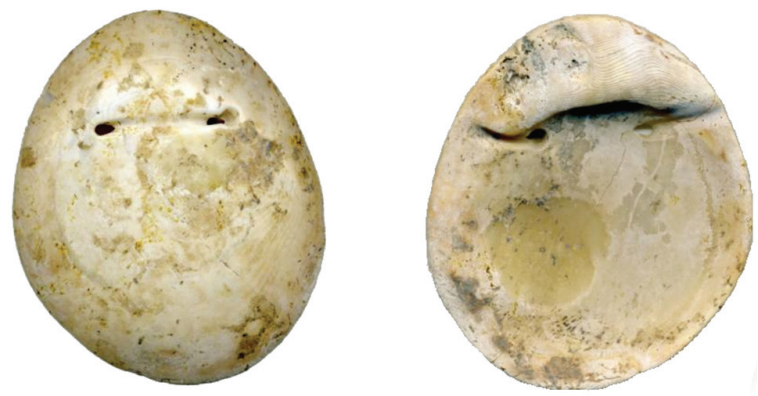

Fig. 6. The largest pendant made of left Spondylus gaederopus valve, Čepin-Ovčara hoard (Museum of Slavonia, inventory no. 155438).

were all strung in the same way, and hung on a string tied around the body and sitting approximately horizontally. This leads to the assumption that the objects served as segments of a belt.

However, we cannot be entirely sure. For the majority of decorative objects, the way in which they were worn can only be ascertained when they are discovered on the body of a burial, or if they are explicitly shown in depictions. However, this, should not impede the examination of the characteristics that the 15 objects share or recognising the strong possibility that they were parts of a whole, or attempts to reconstruct the way they were worn. The pendants were probably not attached to a piece of textile or some other kind of material. If they had been, the impressions of the string would have remained in the area between the holes and the edges on the flat side of the pendants, because the string would have been run through the fabric immediately under the holes. The string imprints are deeper and more pronounced on the flat back side than on the front. This is probably because on the front side the string was firmly fixed between the two holes, whereas it was relatively loose between the segments and could move. There are no traces along the edges to indicate that two neighbouring segments rubbed against each other, so it can be supposed that there was some space between the segments.

The largest of the pendants, made from left valve of the shell, is at least 2.5 times higher than any other pendant in this group, and its weight is 6.5 times greater (Tab. 2). Hence it can be safely assumed that it was placed in the centre, because its weight would pull the belt downwards. There are 14 other segments, of which seven were probably placed on each side of the central piece (Fig. 7). They were probably arranged in descending order of size, from the largest piece placed next to the central pendant, 
down to the smallest, i.e. of the smallest height, placed at the end of the row. The traces left by string in the area between the holes and the lateral sides can, to some extent, help infer whether an individual piece was placed to the left or right of the central pendant. In most segments, the string imprints on either the left or the right extend somewhat obliquely upwards. This could be due to the central pendant pulling the string of the belt downwards with its weight, which means that the other belt segments were slanted, and the intensity and angle at which the string made marks on the surface to the left and to the right of the holes were variable. Clearly, the arrangement of the individual segments could have been different, and almost certainly changed during use, given the traces of modifications and repair on some of the pieces.

As well the two usual holes, one of the segments (Figs. 4.9; 8.b; No. 14 in Tab. 2) has another complete hole and a portion of a hole positioned on the lateral side. Initially, a larger object was created with a pair of holes. It seems that the object was used for a short time before it was fractured across one of the holes. After it got broken, a pendant of different orientation was made, two new holes drilled, and the lower edge of the primary trapezoid was cut so as to again obtain a trapezoid, but this time

\begin{tabular}{|lcccccc}
$\#$ & $\begin{array}{c}\text { Museum } \\
\text { inventory }\end{array}$ & $\begin{array}{c}\text { height/lenght } \\
(\mathbf{c m})\end{array}$ & $\begin{array}{c}\text { width } \\
(\mathbf{c m})\end{array}$ & $\begin{array}{c}\text { thickness } \\
(\mathbf{c m})\end{array}$ & $\begin{array}{c}\text { diameter } \\
\text { of holes }(\mathbf{c m})\end{array}$ & $\begin{array}{c}\text { weight } \\
(\mathbf{g r})\end{array}$ \\
\hline 1 & 155423 & 3.2 & 2.9 & 0.4 & 0.3 & 11 \\
\hline 2 & 155424 & 2.7 & 2.4 & 0.4 & 0.3 & 7 \\
\hline 3 & 155425 & 2.7 & 2.8 & 0.4 & 0.3 & 7 \\
\hline 4 & 155426 & 3.2 & 3 & 0.5 & 0.4 & 9 \\
\hline 5 & 155427 & 3.2 & 2.8 & 0.5 & 0.3 & 7 \\
\hline 6 & 155428 & 2.2 & 1.7 & 0.3 & 0.2 & 2 \\
\hline 7 & 155429 & 2.4 & 1.6 & 0.3 & 0.3 & 3 \\
\hline 8 & 155430 & 2.7 & 2.3 & 0.3 & 0.4 & 4 \\
\hline 9 & 155431 & 2.5 & 2.3 & 0.4 & 0.3 & 4 \\
\hline 10 & 155432 & 2 & 1.7 & 0.3 & 0.3 & 2 \\
\hline 11 & 155433 & 1.8 & 2.5 & 0.4 & 0.3 & 4 \\
\hline 12 & 155434 & 2 & 1.8 & 0.3 & 0.3 & 3 \\
\hline 13 & 155435 & 2.2 & 1.4 & 0.3 & 0.3 & 2 \\
\hline 14 & 155436 & 2.3 & 1.9 & 0.3 & 0.2 & 3 \\
\hline 15 & 155437 & 3.9 & 1 & 0.4 & 0.3 & 3 \\
\hline 16 & 155438 & 8.5 & 7.3 & 0.5 & 0.4 & 71 \\
\hline
\end{tabular}

Tab. 2. List of spondylus pendants from the Čepin-Ovčara hoard.

one of smaller dimensions. The two new holes bear the usual string marks, only now the incisions are somewhat shallower compared to those in the other pendants in the collection.

Pendant No. 11 (Figs. 4.8; 8.a) is trapezoidal, but unlike all the other examples, its height is less than its width. Moreover, the lower edge is curved and damaged. The damage is the most likely reason for 'shortening' the originally regularly shaped trapezoid of which the height is greater than the width. There are traces of two holes - the drilling of which had started but was soon abandoned - under the
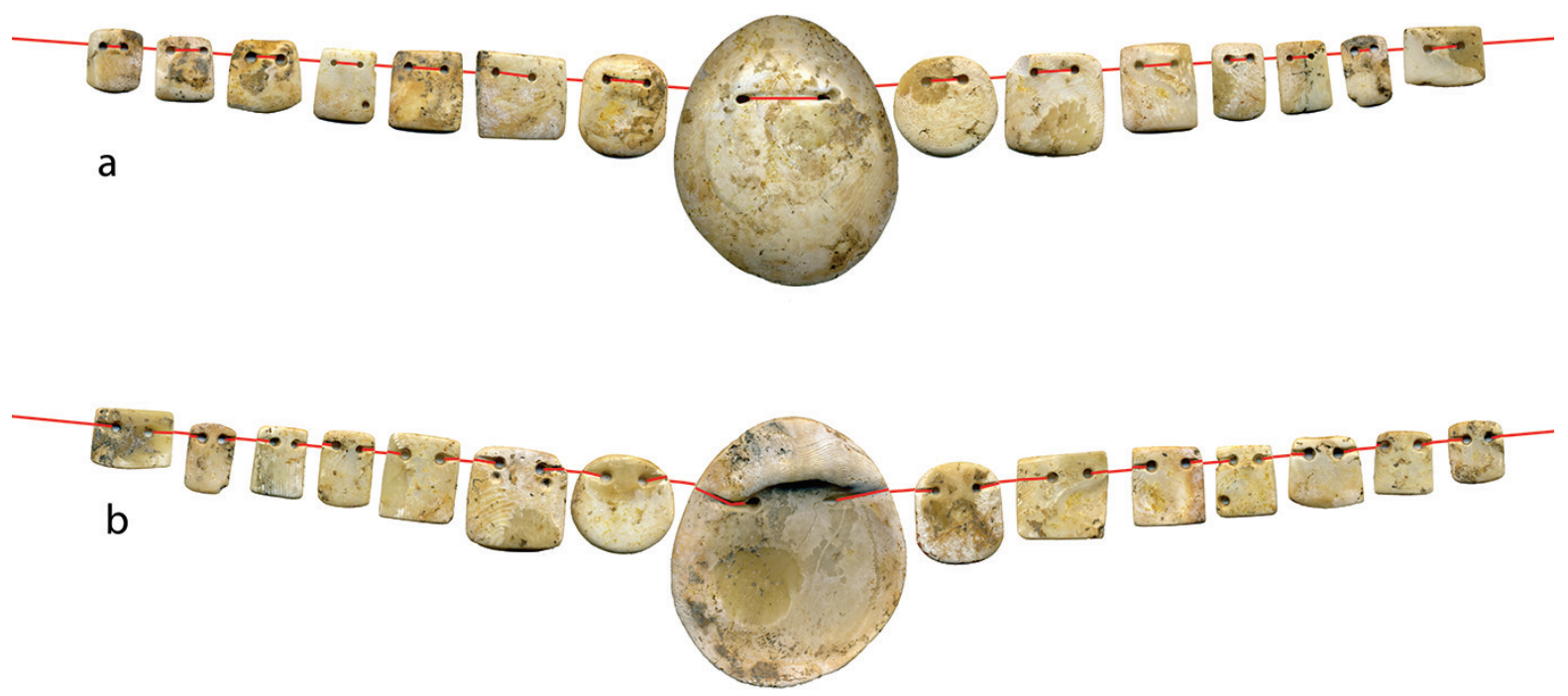

Fig. 7. Reconstruction of the belt made of spondylus pendants: a outer surface, turned away from the body, b inner surface, facing the body. 
perforations on the flat back side of pendant No. 1 (Figs. 4.7; 8.c). This initial drilling was probably attempted prior to opening the holes that were actually in use, but was abandoned because the position of the drilling was too far from the upper edge.
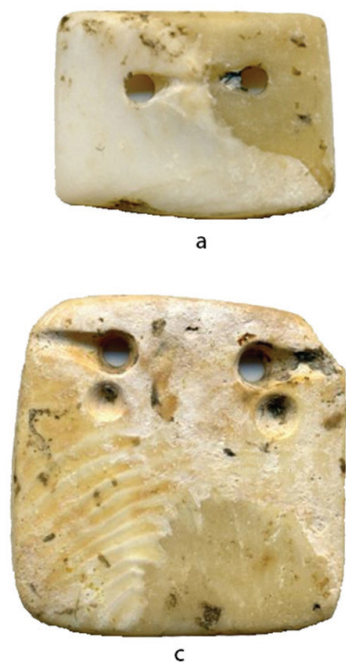

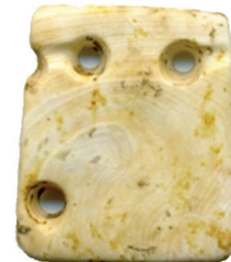

b

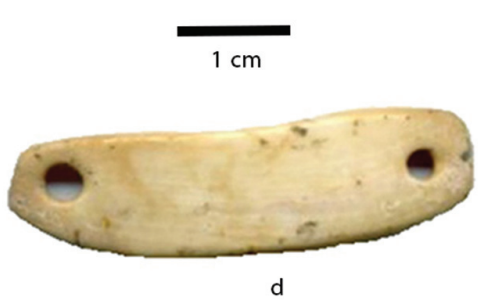

d cumented on pendant No. 1 (Fig. 8.c) where two unfinished holes are preserved.

Finally, it should not go unnoticed that the

Fig. 8. Examples of spondylus pendants, Čepin-Ovčara hoard (specimens No. 11, 14, 1 and 15 in Table 2).

beauty of this exclusive composite ornament lies in the similarity between the segments in the proportions and the location of the holes, but that despite this, each segment is unique. This beauty in the contrast between similarities and differences between the pieces is greatly enhanced by the material from which the pieces were created. The material gives them all a translucency and pretty, bright, ivory colour, but it also renders them unique, since the different irregularities of the shell surface and the

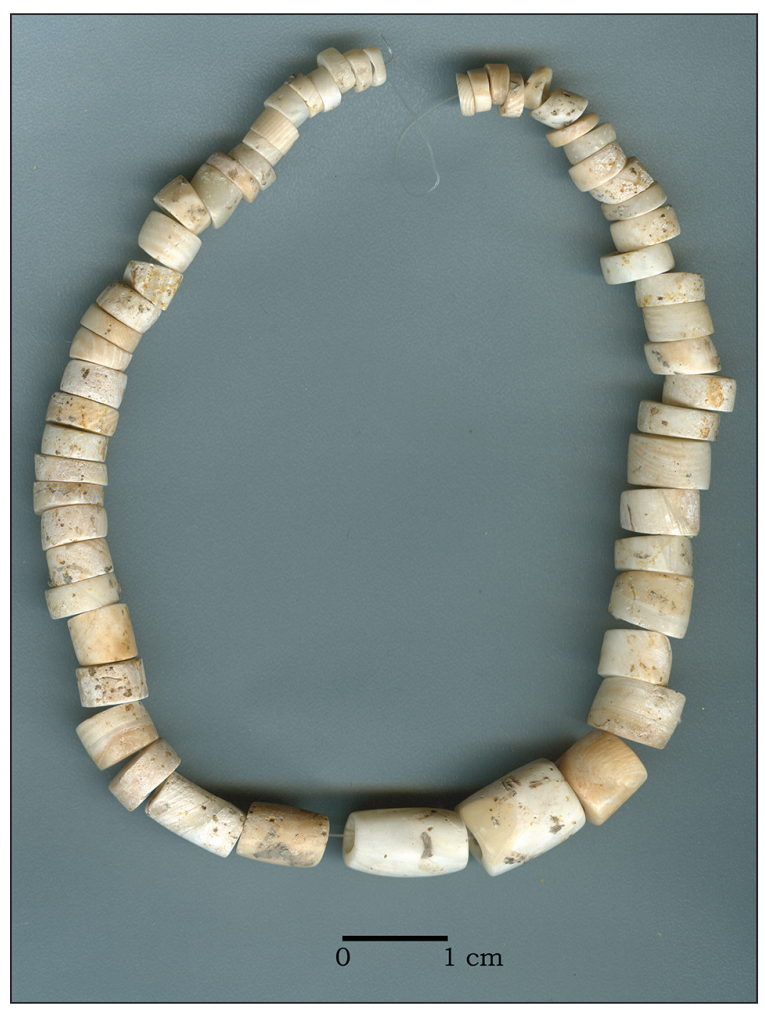

Fig. 9. Spondylus beads arranged in a string. $\check{C} e-$ pin-Ovčara hoard. different exposed sections of the internal shell structure renders each pendant distinct. Above all, and certainly not of least importance for the aesthetic, but also symbolic perception of the individual pendants, is their remotly anthropomorphic character, achieved by placing the string holes in such a way that they remind one of human eyes.

The pendant shaped as an elongated oval (No. 15 in table 2; Figs. 4.14; 8.d) could have been an element of the belt and served as a kind of a safety pin; or it could have had a similar purpose, but as an element of one of the necklaces; but it could have also been worn on its own. The holes are located at the edges, and no string marks are visible on either the outer or inner surface. However, the areas around the holes appear polished, and it is possible that the string was pulled through both of the holes. The string could have been tied into a not on the convex outer side of the pendant, and sown onto a textile or some other kind of material.

\section{The string of spondylus shell beads}

The string consists of 58 discoid beads of various dimensions, diameters and heights (Figs. 5.a; 9). The majority of beads (79.3\%) are up to $4 \mathrm{~mm}$, and as many as $91.3 \%$ are $6 \mathrm{~mm}$ long (Fig. 10). They are made of the same material used for the pendants of the belt. Alternating wavy growth lines characteristic of the different sections through the spondylus shell valves are also visible on the beads. The diameter of the stringing holes is $0.3 \mathrm{~cm}$ and is uniform in all the beads. The standardised diameter of the stringing holes indicates that the beads belong to the same necklace. When they are string together, the length of the string is $19 \mathrm{~cm}$. 


\section{The string of dentalium shell beads}

The cylinder-shaped beads made of significantly thinner shell than that of spondylus were probably also strung as a single item (Figs. 5.b-c; 11). There are 386 of them, and when strung, the length of the string is $128 \mathrm{~cm}$. Scaphopods shells ${ }^{1}$ were used for making these beads. These animals are characterised by a cylindrical shell open at both ends, which can thus be used as a pendant or a bead without modification. Large amounts of these shells have been found at archaeological sites dated from the Palaeolithic onwards (Zilhão 2006; Bar-Yosef Mayer, Gümüs 2010; Ivanova 2012) and a number of their possible uses have been recorded in traditional communities (Sprague 2004; Barton 1994). In the archaeological literature, these shells or, rather, ornaments made from them, are commonly referred to as dentalium, after the best-known genus Dentalium.

The beads from Čepin are 1.5-14.2mm long (their average length is $6.3 \mathrm{~mm}$ ), whereby $69 \%$ of the beads are $4-8 \mathrm{~mm}$ long (Fig. 12). The thickness of the shell is about $0.2 \mathrm{~mm}$; it is smooth, ivory in colour and translucent (Fig. 13). This shows that the shells are modern, not fossilised ${ }^{2}$. None of the shells is complete; instead, all the beads were produced from transversely broken shells. On the beads made from the back, tapered end of the shell, one can observe fine longitudinal lines that gradually become faint

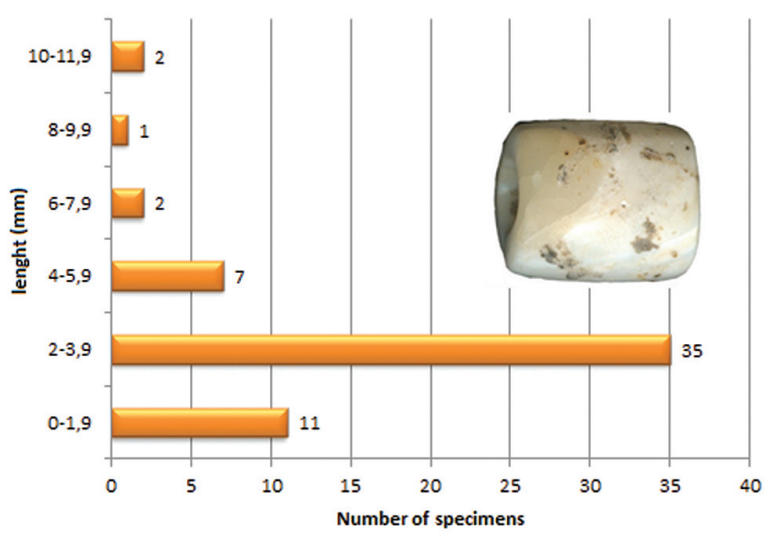

Fig. 10. Distribution of lenghts of spondylus beads. Čepin-Ovčara hoard. towards the very end and blend into the smooth surface. This type of shell surface pattern is characteristic of Antalis vulgaris 3 . No traces of cutting were detected. The rounded edges of the beads suggest that, instead of complete shells and subsequent transverse cutting to obtain beads of the desired length being used, already broken shells were collected and used. However, this hypothesis should be tested by observing the shells under greater magnification than the one used for this study. In the vast majority of beads, the edges were routinely rounded, i.e. smoothed and rounded naturally. A number of beads have spout-like protrusions around the edge, which indicates that they were broken along the growth lines 4 . They were probably collected on beaches where the waves leave shells of decomposed organisms; as waves roll ashore, they crush the shells and sand smooth their edges. The presence of tiny dimples on the surface of some shells confirms this impression; these occur as a result of the activity of so-called drilling organisms5. Given that scaphopods live buried in mud, these organisms inhabit the shell only if it is empty.

\section{The Čepin hoard in a regional context}

In Europe, Spondylus shell ornaments were in use between the $7^{\text {th }}$ and $4^{\text {th }}$ millennium $\mathrm{BC}$, whilst their distribution was widest - from the Aegean Sea to the Paris Basin - between the mid-6th and mid-5th millennium BC (Müller 1997; Seferiades 1995; Windler 2013). Over the three millennia, the ornaments were manufactured exclusively from contemporary shells. The results of previous (Shackleton, Renfrew 1970; Schakleton, Elderfield 1990) and new stable isotope analysis (Bajnóczi et al. 2013) suggest that the shells were sourced in the eastern Mediterranean, i.e. from the Aegean and/or the Adriatic Sea. Based on the archaeological data from the coastal zone, researchers agree that the Aegan region was an important shell source throughout this period, and that both jewellery and shells were transported from here to the mainland of the Balkan Peninsula, and later all the way to the west coast of the

\footnotetext{
1 Scaphopoda means 'shovelfoot' $($ scapho $=$ shovel, poda $=$ foot $)$ and the term refers to the organ located at the wider end of the shell and which serves for burrowing in sand or moving through sea sand and mud. They are also commonly known as 'tusk shells' because their shells are conical and curved, making them look like miniature tusks (Dimitrijević, Tripković and Jovanović 2010).

2 See the description of differences between fossilised and modern shells in Dimitrijević and Tripković (2006). The paper describes decorative objects made of modern shells (i.e. coeval with the archaeological finds) Spondylus and Glycymeris and of Miocene dentalium shell.

3 Antalis vulgaris Da Costa, 1178, formerly determined as Dentalium vulgare.

4 Naturally broken and rounded fossil dentalium shells used as beads at the site of Vinča - Belo Brdo had a similar shape (Dimitrijević, Tripković and Jovanović 2010). Also, based on the similar taphonomical characteristics of shells, Bar-Yosef Mayer (2008) concluded that in the prehistory of the Levant, primarily in the Natufian, shells collected on beaches were used as beads.

5 Primarily Bryozoa (moss animals).
} 
Black Sea. From the mid-6th century, items made of spondylus were frequent at sites along the Danube and its tributaries; this led to the conclusion that the Danube corridor was the main route for transporting and exchanging goods in the central part of the European continent (Chapman 1981). The interfluves of the Sava, Drava, and Danube formed an integral part of the continental route, which may explain the origin of the ornaments in the Sopot culture settlement.

Still, there are different opinions on the origin of the ornaments found in continental Europe. For instance, spondylus items discovered in Central Europe and the Carpathian Basin have characteristics documented region-wide; however, the frequently found large belt buckles are absent from the Aegean and the eastern Balkans. This led to the assumption that ornaments from central Europe was manufactured from shells obtained from a different source, i.e. from the Adriatic (Müller 1997). As has recently become increasingly evident, the Neolithic communities of the eastern Adriatic undoubtedly used and created spondylus ornaments (Batovic 1979; Kukoč 2012). They probably established and maintained communication with communities in the hinterland (Batovic 1979). The best evidence for these contacts derives from the settlements in central Bosnia, Obre I from the Early Neolithic (Benac 1973) and Obre II from the Late Neolithic (Benac 1971), where the material culture bears numerous characteristic of the Adriatic cultural circle, and where spondylus items were also documented (Fig. 14.a). This indicates that the inhabitants of the central Bosnian settlements possibly mediated the northward distribution of valuable objects from the Adriatic. The closest areas in the neighbourhood, and located on this route, are the interfluves of the Sava, Drava, and Danube.

Unlike spondylus, for the manufacture of dentalium beads, both fossil and contemporary shells were used. The regional distribution and ubiquity of objects made of dentalium are still not well understood. According to the available data, in the middle Danube area and the Carpathian Basin, the beads occur most frequently during later prehistory; these are chiefly examples of the use of fossil shells (Todorova 1995; Dimitrijević, Tripković and Jovanović 2010; Girić 1971; Sümegi 2009; Sztancs, Beldiman 2010). They are relatively common at the Lengyel sites in south-eastern Transdanubia (Siklósi 2013) and at the Vinča-Belo Brdo site in Serbia (Dimitrijević 2014). As regards the Vinča site, it was estab-

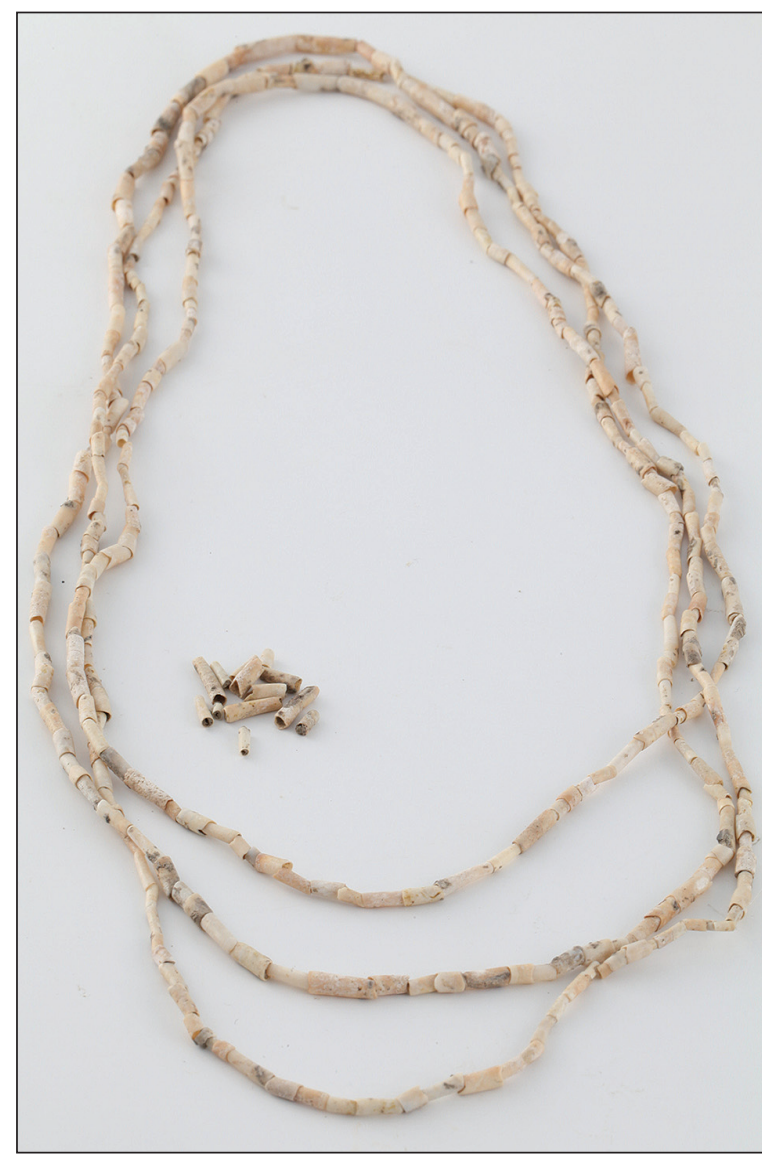

Fig. 11. Čepin-Ovčara hoard. Antalis vulgaris beads arranged in a string.

lished that the shells were procured from a Miocene outcrops in the vicinity of the settlement (Dimitrijević 2014; Dimitrijević, Tripković and Jovanović 2010).

Beads made from contemporary shells, such as those in the Čepin-0včara hoards, have not been documented at other sites in the Slavonian and Srem regions, and are also very rare in the wider area ( $D i$ mitrijević, Tripković and Jovanović 2010). However, they are frequently found in the Aegean (Karali 1999; Nikolaidou 2003) and along the Black Sea coast, while they are especially abundant at the necropolises at Durankulak and Varna (Todorova 2002; Avramova 2002). Given that scaphopods do not live in the Black Sea, it is assumed that people in this region acquired them through sea trade, probably with the Aegean, and that the subsequent exchange was confined to the local coastal areas (Ivanova 2012). The scaphopod shells that are the focus of this paper could have originated from the Adriatic, which is $300 \mathrm{~km}$ away as the crow flies from the Čepin site. However, they could as well have originated from other parts of the Mediterranean Basin such as the Aegean. 


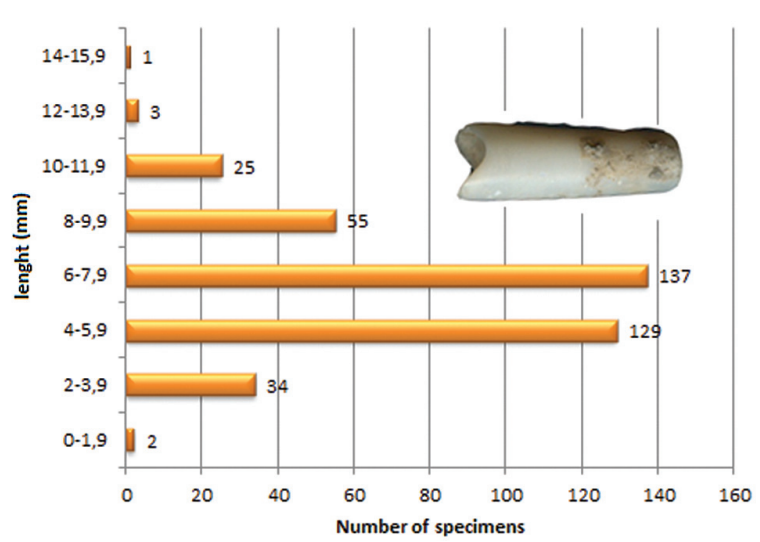

Fig. 12. The distribution of lengths of Antalis vulgaris beads. Čepin-Ovčara hoard.

Considering the variations between Neolithic sites in the distribution and ubiquity of adornments made of spondylus and dentalium, it is possible that they were acquired in different ways. Spondylus items exchange was a matter of cultural routine in the Neolithic, and a number of people were involved in its production, procurement, use, and re-working. This is supported by the long use-period of the objects in the Čepin hoard. The lack of evidence in the wider region of the use of contemporary scaphopod shells might suggests that the bead necklace from the hoard was not obtained via the same communication route used for obtaining objects made of spondylus. Furthermore, very few intermediaries or, rather, acquisition directly from the source of the raw material, perhaps better explain the mechanism by which the beads were obtained.

\section{Distribution and use of the ornaments}

During later prehistory, objects made of shells of marine organisms were commonly used as ornaments. Those made from a complete valve of Spondylus shell are particularly ubiquitous in the Carpathian Basin and central Europe (Müller 1997; Kalicz, Szénászky 2001). They are frequently found in graves; based on their find location near the abdomen of the deceased, and/or the traces of use, it was determined that they were used as belt buckles (Nieszery, Breinl 1993). This type of ornament, more than any other, demonstrates that regions and cultures had specific requirements in terms of the manufacture, appearance and use of the objects. Thus the clasps with V-shaped opening were made exclusively from the right valve of the shell, and the opening served as part of the buckling mechanism. These are typical of the Linearbandkeramik culture of central and western Europe and were usually found only in male graves (Müller 1997; John 2009). They very rarely occur in other regions; in the southern Balkan
Peninsula they are known only from the sites at Dispilio (Ifantidis 2009) and Alepotrypa Cave (Papathanasopoulos 1996) in Greece. In contrast, pieces with two perforations, identical to the example from the Čepin hoard, were manufactured from the left valve of the shell. These are particularly common in female graves in the Carpathian Basin during the period of Alföld Linear Pottery and the early Tisza culture (Kalicz, Szénászky 2001; Siklósi 2004; 2013). The reconstruction of their use suggests that they represented the central part of a belt (Nieszery, Breinl 1993). A specimen of spondylus valve, that is most probably belt buckle with multiple perforations, was recently discovered in a grave 476 (unsexed adult, aged 18-20 years) at the Sopot culture site Alsónyék-Bátaszék (Oross et al. 2016). Date 0xA28246 obtained on human rib places the grave in the period from 5135 to 4995 cal BC (at 93\% probability). Besides in Čepin hoard, no other finds of spondylus valves have been found at the Sopot culture sites in the Sava-Drava-Danube interfluves. Some $40 \mathrm{~km}$ to the east of the site, however, a similar object was discovered at Mostonga near Odžaci (Serbia) in a grave dating from the early Vinča culture (Karmanski 1977.Pl. 7).

In the Sava-Drava-Danube interfluves (Fig. 14.b), other objects made of marine shells are encountered throughout the Neolithic. Yet, their number increases through time and particularly towards the final Neolithic. From the Early Neolithic (Starčevo culture), a small pendant with two perforations made of spondylus was discovered in the settlement at TržnicaVinkovci, in the grave of a child placed in a flexed position (Dimitrijević 1979.241; Burić 2009.Fig. 24). At Zlatara near Ruma, three spondylus beads were recovered from the grave of a woman of 40-45 years of age (Leković 1985).

The largest number of objects made of marine shells from the Sopot culture, is from the Čepin-Ovčara site. Besides the finds in the hoard, three more pendants

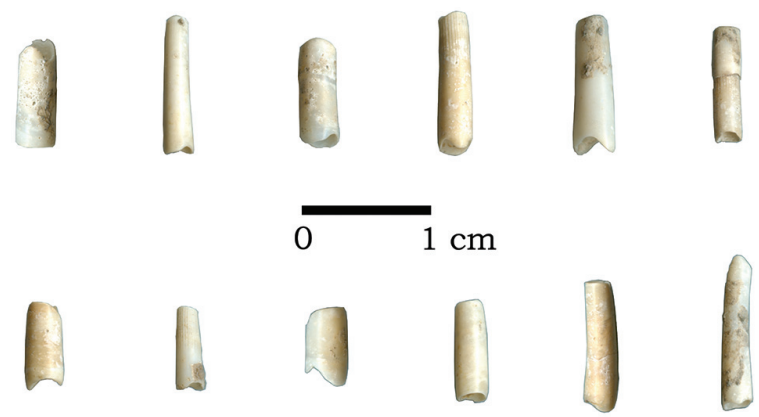

Fig. 13. Examples of Antalis vulgaris shell beads. Čpin-Ovčara hoard. 
and nine fragments of spondylus bracelets were discovered elsewhere in the settlement ${ }^{6}$. Pendants and fragmented bracelets found in the settlement at Gradac-Bapska (Burić 2009.22, 47, Fig. 5, 46, 66; 2011; 2014.9), two pendants with perforations from Sopot-Vinkovci (Dimitrijević 1968.47, Pl. XVI/1, Pl. XX/7; 1979.267, 292; Balen 2006.28-29), and ornaments from Štrbinci near Djakovo (Dimitrijević 1979.292) derive from the same period. Also, at least 19 spondylus items were unearthed at Filipovica/Hermanov vinograd near Osijek, including mainly rectangular and oval pendants with two perforations, fragments of bracelets and a bead (Šimić 2006.40; 2008.34-35).

The regional assemblage of marine shell ornaments is completed by the objects from, probably, graves found by chance at Željeznička stanica (a bracelet and beads) and Lijeva Bara (three bracelets) in Vukovar, dated to the Neolithic/Eneolithic (Brunšmid 1902.63-64, Fig. 20; Kukoč 2012; Chapman, Gaydarska and Balen 2012). Furthermore, three cylindrical beads of various sizes and unknown provenance are today kept at the Museum of Slavonia in Osijek (Inventory no. 896). Lastly, a pendant and an elongated cylindrical spondylus bead were discovered within an early post-Vinča culture horizon at Gomolava in eastern Srem (Serbia), in a layer that yielded a combination of material associated with the Sopot and Tiszapolgar cultures (Brukner 1981.24-25).
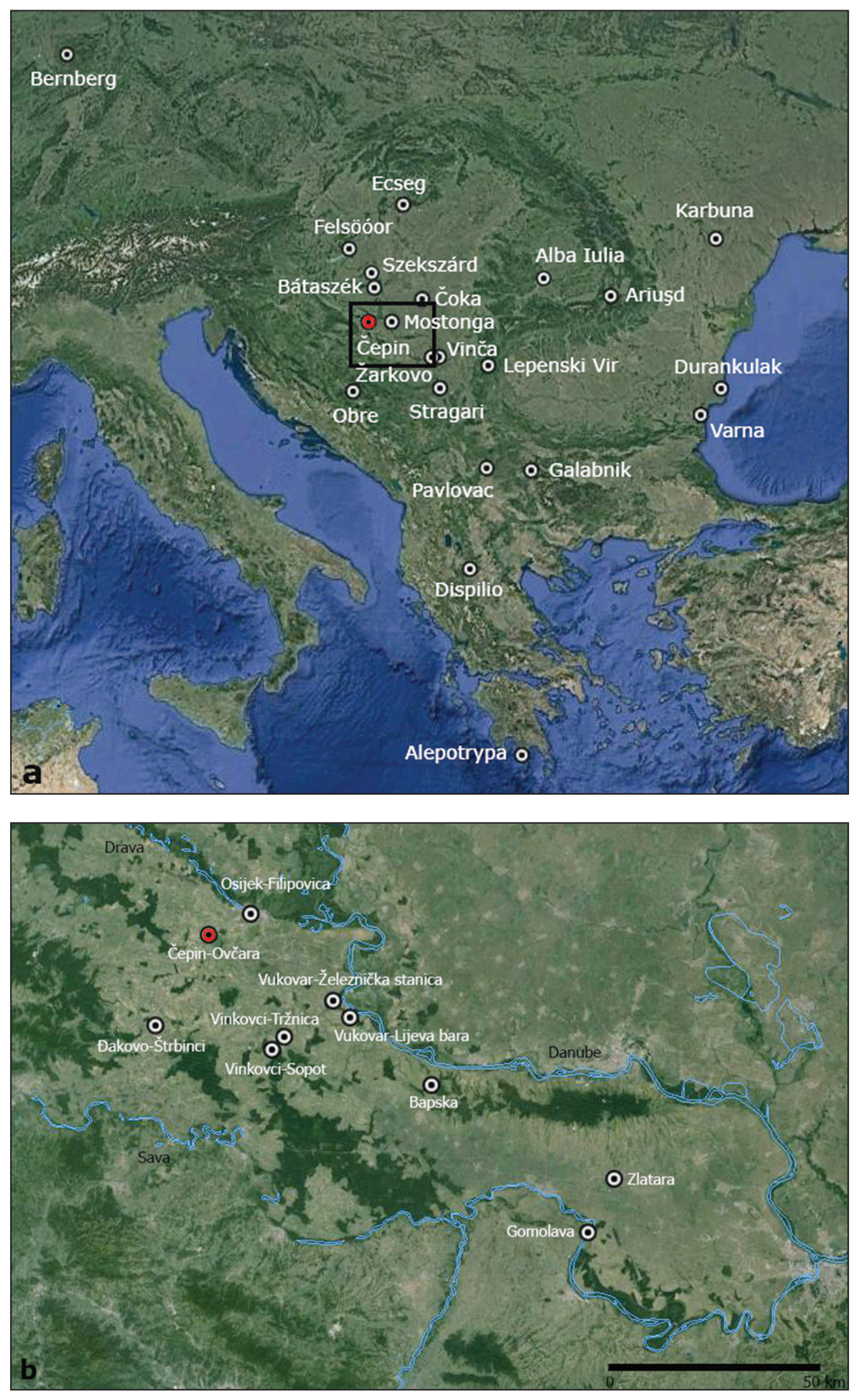

Fig. 14. Neolithic sites with finds of marine shell items mentioned in the text: a in the Carpathian Basin and South-East Europe, $\mathrm{b}$ in the area defined by the rivers Sava, Drava and Danube (area marked by a square in Fig 14.a). Adapted Google Earth picture.

It appears that the inhabitants of Late Neolithic settlements in the interfluves of the Sava, Drava, and Danube generally used smallish oval and rectangular pendants with two perforations, like the ones predominant in the Čepin hoard. Pendants of similar design and dimensions were documented at the nearby Late Neolithic sites of Sopot (Dimitrijević 1968), Hermanov vinograd (Šimić 2006; 2008) and Bapska

(Balen 2006; Burić 2011), as well as at the ČepinOvčara settlement itself (unpublished, Museum of Slavonia, Osijek). The traces of use of these pendants have not been described, and the published photographs and drawings are usually insufficient to conclude how the objects were worn. In the photographs and drawings of the pendants from Bapska and Sopot that show only one side, usually the front, of the objects, imprints of string are visible between the two holes (Fig. 15).

6 The objects have not been published and are kept in the Museum of Slavonia in Osijek. 
However, at least one of the pieces from the site at Hermanov vinograd (unpublished; inventory no. AP1454, Museum of Slavonia in Osijek), and another from Sopot (Burić 2011.112, Fig. 36), also have horizontal incisions that extend from the perforations towards the edge of the objects, suggesting that they were attached and worn in the same manner as the pendants from the hoard described here. A detailed analysis of use wear on the other pendants from the Sopot culture sites and the wider region is necessary for any further assumptions about the ways in which they were worn. That they could have been strung in different ways is indicated by the example from Vinča, which has two pairs of perforations, one opposite the other, and without visible traces of string impressions (Dimitrijević, Tripković 2006.Fig. 7). If our reconstruction, based on the finds' context and use wear, is correct - that the pendants from the Čepin hoard are parts of a composite belt - the design of the belt can be compared with, and is, in fact, similar to, the depictions of belts on anthropomorphic figurines from the coeval Vinča culture. For instance, some of the figurines from Vinča, Žarkovo, Pavlovac (Fig. 16) and Stragari (Stanković 1988.98) bear representations of a belt in the form of one or more circular applications that reminiscent the ornaments made of spondylus shell. The belts depicted on the figurines from Vinča (not shown in Fig. 15, but see Vasić 1932.Pl. 19.95; 1936.Pl. 32. 158) and Pavlovac (Fig. 16.d) bear the closest resemblance to our reconstruction of the belt from Čepin-0včara.

The remaining objects from the hoard, such as the crescent-shaped pendant with perforations at both ends, and the discoid spondylus beads, do not display any specific cultural or regional characteristics. They could have been created from the previously unworked shells or, through reduction and re-working, from fragmented bracelets and other objects, which contributed to their wide distribution, diversity and abundance (see Todorova, Vaisov 2001.Fig. 2 ). Both types of ornament have been documented at different sites in the immediate vicinity of Čepin, although only the lunular pendant from the settlement at Bapska, with holes at both ends, securely dates to the period of Sopot culture (Balen 2006). For the two bead necklaces, one most probably from a grave at Željeznička stanica in Vukovar and the other from an unknown location near Vinkovci, the context of the finds and the period from which they derive have not been confirmed. The Vukovar necklace is broadly placed in the period from the Late Neolithic to the Bronze Age, although the general opinion is that it is Late Neolithic/Early Eneolithic
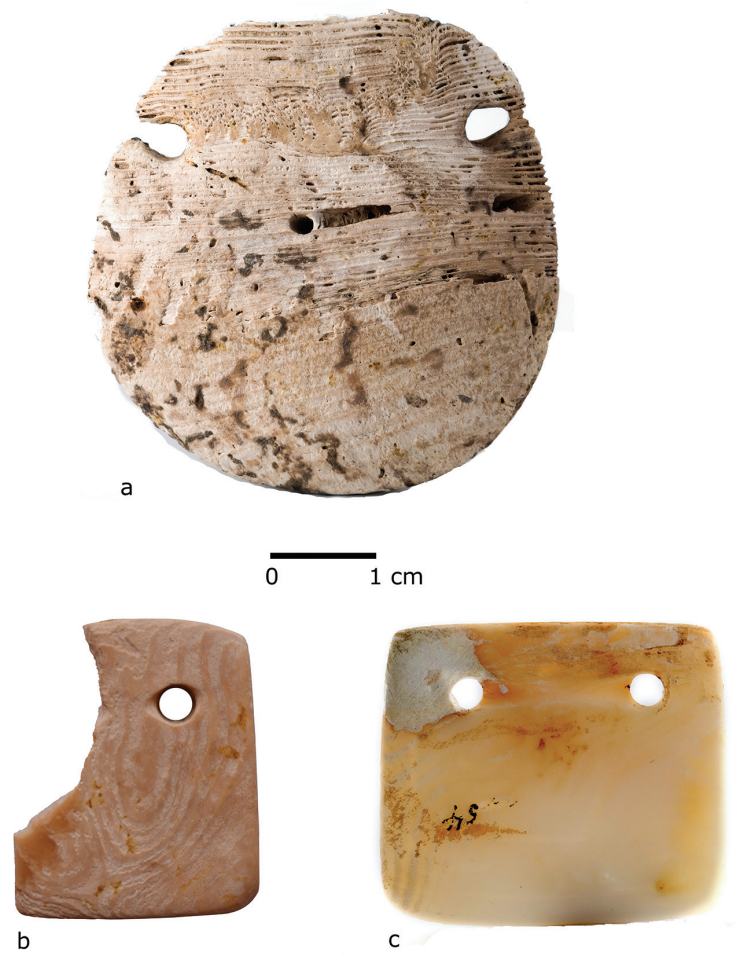

Fig. 15. Spondylus pendants: a Čepin-Ovčara (Rajković 2014); b Čepin-Ovčara (Museum of Slavonia in Osijek, inventory no. 166960); c Hermanov vinograd (Museum of Slavonia in Osijek, inventory no. AP-1454).

(Chapman, Gaydarska and Balen 2012). The necklace is composed of at least 81 discoid beads, $88 \%$ of which is up to $6 \mathrm{~mm}$ thick, which makes them similar to most of the spondylus beads from the Čepin hoard. However, the beads from Vinkovci are different; the necklace consists of 11 large cylindrical beads that, based on the dimensions, probably originate from an earlier period.

There are no useful data from the Sopot sites in the Sava-Drava-Danube interfluves on the ways in which the necklaces were worn. In other regions, spondylus as well as dentalium beads are more abundant in graves characterised by rich offerings for the deceased, and in hoards (Chapman 2000). They were worn in diverse ways. They were usually attached to clothing or strung and worn around the wrist or neck, or as an ornamental headdress (diadem) or decorative belt, and this can be deduced from their various locations in the graves with inhumations ( $A v$ ramova 2002; Ivanov, Avramova 2000; Nieszery, Breinl 1993). An illustrative example, and the one closest to the Čepin-Ovčara site, comes from the Alsónyék-Bátaszék site in south-eastern Transdanubia in Hungary, where 2359 Late Neolithic graves were detected, and some 100 contain rich offerings accompanying the deceased (Osztas, Zalai-Gaal and 
Banffy 2012; Banffy et al. 2014). In one of the graves characterised by a complex funeral ritual, a woman was buried with her body and clothes decorated with numerous ornament pieces. There were bracelets made of spondylus beads on her left and right arms, and spondylus, dentalium and copper/malachite beads on her chest, while particularly impressive is a belt made of spondylus beads wrapped 12 times around the body (Banffy et al. 2014.361, Figs. 14-15).

Given its frequent presence in the graves, seashell adornment must have had a significant role in the construction and reinforcing individual identities. The objects from the Čepin hoard, as elements of a personal set of accessories, had the same purpose, but we cannot determine whether they belonged to one or more persons. The belt clasp with

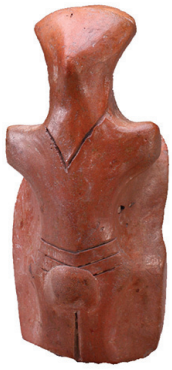

a

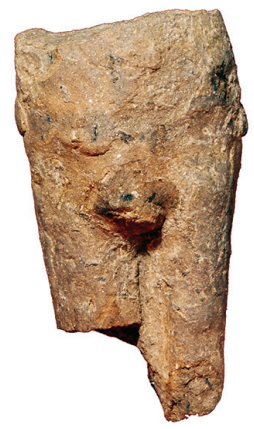

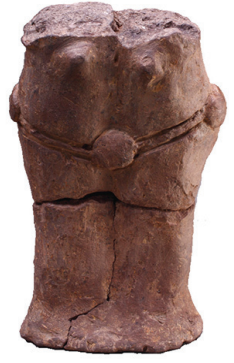

b

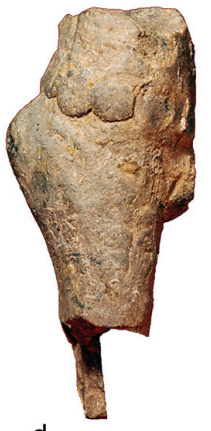

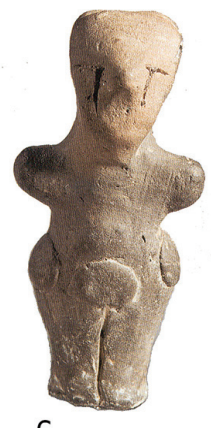

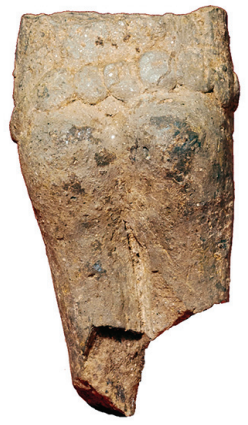

Fig. 16. Representation of belts on the figurines of the Vincra culture: a Vinča (Tasić 2008); b Vinča (Ignjatović 2008); c Žarkovo (Petrović, Katić and Spasić 2009); d Pavlovac (Vuković, Perić 2014). two perforations for stringing was probably part of a woman's dress, as in the Carpathian Basin (Siklósi 2013); based on this, we can assume that at least some of the objects in the Čepin hoard was worn by a female. We cannot, however, be entirely sure about this. The cultural affinities involved in the collection and wearing of ornaments made of sea shells could have varied greatly, as evidenced in the settlement at Vinča near Belgrade (Serbia), which is only $150 \mathrm{~km}$ from Čepin. A number of bracelets made of the Mediterranean clam Glycymeris glycymeris were discovered at this Late Neolithic site beside the Danube (Dimitrijević, Tripković 2006), as well as beads made of fossil dentalium shells (Dimitrijević 2014; Dimitrijevic, Tripković and Jovanović 2010); both are entirely absent at Čepin and other sites in the interfluves of the Sava, Drava and Danube. Besides the previously described certain similarities, the inhabitants of the settlements in the two neighbouring regions were obviously guided by different value systems in the procurement and use of ornaments made of marine shells. Thus investigations of the regional and local specifics concerning the use of seashell adornment remain an important research task.

Spondylus and dentalium in ornament hoards Only about 20 hoards containing spondylus and dentalium ornaments have been documented for the Neolithic and Copper Age of southeast Europe and the Carpathian Basin (Chapman 2000; Siklósi 2013). The instance of spondylus valve with two perforations functioning as a container for storing other pieces of jewellery is not known from other sites. A ceramic vessel was usually used as a container; objects were placed inside, and then everything was stored in the house or deposited within or even outside the settlement (Chapman 2000). The available data reveal that, apart from Čepin, dentalium beads have so far been found only in the Early Neolithic hoard from Galabnik (western Bulgaria) and in the Late Neolithic hoard from Felsöoors (Hungary). In both cases, the jewellery was placed in a ceramic vessel. There were more than 10000 beads made of dentalium, stone and bone in the Galabnik hoard, along with the rings manufactured from spondylus and nephrite (Chapman 2000). The Felsöóors hoard contained 280 objects made of mollusc shells and some stone beads; malacological analysis determined the presence of a fossil species, Dentalium badense (Regenye et al. 2009; cf. Sztancs, Beldiman 2010).

On the other hand, miscellaneous spondylus objects commonly occur in hoards, and sometimes they are the only pieces of adornment in them. Besides Galabnik, the only other Early Neolithic hoard that included spondylus items is the one from Lepenski Vir. This hoard consisted of beads of spondylus and palygorskite, possibly parts of the same bead strand, and 
deposited in a Starčevo culture vessel (Srejović 1969). Some other of the earliest examples of ornament hoards comprised exclusively of spondylus objects and deriving from the second half of the $6^{\text {th }}$ millennium BC from the Carpathian Basin and central Europe include: the Bernburg hoard (Germany) consisting of two bracelets, 178 beads and two pendants/belt pieces deposited in a Linearbandkeramik vessel (Willms 1985.333, Fig. 1); Ecseg hoard (Hungary), probably deriving from the same period, contained a V-shaped belt clasp, bracelets and beads (Siklósi 2013); a chance find (hoard?) from Szekszárd-Palánki-hegy (Hungary) included a valve with two perforations, three massive bracelets and elongated cylindrical beads (Siklósi 2004; 2013); finally, the Alba Iulia hoard from the early Vinča culture should also be mentioned - it comprised two belt clasps and nine large beads (Comsa 1973.71). It is important to emphasise that these hoards include belt clasps, i.e. pendants that have the same purpose and/or shape as the central belt piece from the Cepin hoard.

From the end of the $6^{\text {th }}$ millennium BC, in the wider Middle Danube area, a much greater number of items, made from various materials, were deposited in hoards; this was the beginning of a trend that characterised the following millennium. Two hoards were discovered in the early $20^{\text {th }}$ century in the close proximity of Čepin-Ovčara at a settlement at ČokaKremenjak that combines elements of the early Vinča and the Tisza cultures. Some of the contents of these hoards have been lost over time (Raczky 1994). The Čoka 1 hoard contained items made from marine shells, marble, malachite and animal teeth, and also ochre lumps etc., all placed in a sizeable ceramic pot with two horizontally attached handles. The spondylus objects included 3231 beads, one bracelet and fragments of bracelets, as well as several pendants (Raczky 1994). Čoka 2 comprised similar materials, with pendants manufactured from shell, bone and animal teeth, and stored in a spherical vessel (Raczky 1994). The contents of these hoards clearly demonstrate the practices of collecting, keeping and storing adornment made from various materials, many of which are white, directly signalling the raw material being emulated. This is particularly indicative in the case of two objects from the Čoka 1 hoard (Raczky 1994.Pls. 1, 3.1-2), which are made of marble and appear similar to the large belt buckles made of spondylus.

The trend of collecting and cache-depositing various objects can be considered a hallmark of the $5^{\text {th }}$ mil- lennium $\mathrm{BC}$ in the broader region, best exemplified by the hoards at Ariussd (Romania) and Karbuna (Moldavia) in eastern Europe. In the hoard from Ariuşd (Ariuşd culture, Cucuteni-Tripolye cultural complex) more than 2233 objects were deposited in two pots with lids found within a possible residential structure (Sztáncsuj 2005). The majority of items were made of copper (1938 beads and six bracelets), while the rest of the hoard consisted of bone pendants and plaques, animal teeth pendants, stone beads, gold twisted wire and plaques made of freshwater shells, as well as over 40 objects made of spondylus (Sztáncsuj 2005). Among these, fragmented lunular pendants, often with preserved one or two perforations, predominated; some of them showed traces of repair (Sztáncsuj 2005.95). The shape of these objects renders them very similar to the crescent-shaped pendant from the Čepin hoard. The hoard from Karbuna (Tripolye A culture) contained 852 objects made of copper (beads, appliqués and axes), stone (axes), beads made of red deer teeth, and ornaments made of marine shells, all placed in a ceramic container. The spondylus assemblage includes 254 beads, plaques and bracelets.

The Ariuşd and Karbuna hoards consist of a large number of spondylus ornaments, but they are not the principal component. Instead, copper prevails, as it was a raw material whose importance significantly increased during the $5^{\text {th }}$ millennium BC. The expansion of choice of raw materials took place in the Carpathian Basin and eastern Europe in parallel to the process of disintegration of Neolithic social and economic networks that had for centuries facilitated the exchange of spondylus objects. From the mid-5 ${ }^{\text {th }}$ millennium BC onwards, spondylus hoards were deposited only in the eastern Balkans (Chapman 2000). They mainly contain chipped stone tools, fragmented bracelets and beads. During this period, the circulation of items made of Mediterranean seashells ceased on the European mainland, and the traditional ornaments were replaced by ornaments manufactured from other materials (Georghiou 2012). The best evidence of continuity of use and the significance of ornaments over this period comes in the form of a representative hoard from $\mathrm{Brad}$ in east Romania dated to phase $\mathrm{A} 3$ of the $\mathrm{Cu}$ cuteni culture, i.e. the late $5^{\text {th }}$ millennium BC ( $\mathrm{An}$ thony 2010). In addition to the numerous pendants made of deer teeth and various copper objects, the hoard included five copper and gold discs which, judging by their shape, size and probably also function, mimic the traditional spondylus pendants and belt clasps from earlier periods. 
Although they derive from different periods, all of the described hoards share a characteristic that can help us better understand cross-cultural patterns in the procurement and deposition of ornaments crafted from exotic seashells. It is worth noting that the locations at which the hoards were registered are distributed along the edge of the area of exchange across the continent of ornaments made from Mediterranean shells. During the first half of the $5^{\text {th }}$ millennium, when the Čepin hoard was deposited, the amount of spondylus objects reaching western and central Europe had already decreased, and the Carpathian Basin was the last major centre in continental Europe where the exchange and use of Mediterranean items was intensive (see Windler 2013). Thus, if the hoards indeed reflect inter-communal relationships, as suggested by Chapman (2000), then the reasons for hoarding of ornaments should also be sought in the realm of the intensive social competition that characterised the Late Neolithic of the region. Just as the objects were acquired for social display, we expect that they were deposited in hoards in order to be secured and/or concealed.

\section{Conclusions}

The only hoard of marine shell ornaments to have been discovered in the interfluves of the Sava, Drava, and Danube was discovered in the Sopot culture settlement at Čepin-0včara. It was found next to a house belonging to the latest settlement horizon of the Sopot culture. The ornaments in the hoard included two strands of strung beads made of shells of Spondylus gaederopus and a scaphopod Antalis vulgaris, and 15 pendants made of Spondylus gaedero- pus that are, based on their use wear, here interpreted as segments of a belt. Pendants have distinct traces from being worn and re-worked, which led to the conclusion that they had been in use for a long time before being placed in the hoard.

Across the Danubian region, similar objects were widely used for decorating the body and clothing; only in hoards and graves furnished with rich offerings for the deceased have they been found in very large quantities. Unlike these, the beads made of $A n$ talis vulgaris shell are unique examples in the region. They have been known only from the Aegean and eastern Balkans, which indicates that the dynamics and mechanism of their exchange in inland areas were different. Nonetheless, both types of ornaments document that, during the Late Neolithic, body adornment and clothing accessories were important aspects of social life in the Sava-Drava-Danube interfluves, and that ornaments made of Mediterranean marine shells played a particularly important part in it.

\section{ACKNOWLEDGEMENTS}

The authors are grateful to Jasna Šimic, director of the archaeological project at Čepin-Ovčara, for her kind support. We are also grateful to Jacqueline Balen, Rajna Šošić-Klindžić and Maja Andrič for their valuable comments on this paper. Agathe Reingruber provided some useful references. Research of $B$. $T$. and $V$. D. was conducted within the project Bioarchaeology of Ancient Europe: Humans, Animals and Plants in Prehistory of Serbia (project no. III 47001) sponsored by Ministery of Education, Science and Technological Development of Republic of Serbia.

\section{References}

Anthony D. W. 2010. The Rise and Fall of Old Europe. In D. Anthony, J. Y. Chi (eds.), The Lost World of Old Europe. The Danube Valley, 5000-3500 BC. Institute for the Study of the Ancient World. New York UniversityPrinceton University Press. New York, Princeton: 28-57.

Avramova M. 2002. Der Schmuck aus den Gräbern von Durankulak. In H. Todorova (ed.), Durankulak. Die Prähistorischen Gräberfelder von Durankulak. Band II. Deutsches Archäologisches Institut. Sofia, Berlin: 191-206.

Balen J. 2006. Neolitik. In S. Mihelić (ed.), Trgovina i razmjena u prapovijesti. Arheološki muzej u Zagrebu. Zagreb: $25-32$.
Balen J., Čataj L. 2014. The Sopot Culture. Gifts of the Earth. In J. Balen, T. Hršak and R. Šošić-Kindžić (eds.), The Neolithic between the Sava, Drava and Danube. Museum of Slavonia, Archaeological Museum and Faculty of Phlosophy. Osijek, Zagreb: 59-73.

Balen J., Hršak T. and Šošić-Klindžić R. (eds.) 2014. Gift of the Earth. The Neolithic between the Sava, Drava and Danube. Museum of Slavonia, Archaeological Museum and Faculty of Phlosophy. Osijek, Zagreb.

Bajnóczi B., Gabriella Schöll-Barna G., Kalicz N, Siklósi Z., Hourmouziadis G. H., Ifantidis F. Kyparissi-Apostolika A., Pappa M., Veropoulidou R. and Ziota Ch. 2013. Tracing 
the source of Late Neolithic Spondylus shell ornaments by stable isotope geochemistry and cathodoluminescence microscopy. Journal of Archaeological Science 40: 874-882.

Bánffy E., Zalai-Gaál I., Marton T., Oross K., Osztás A. and Petrasch J. 2014. Das Sárköz im südungarischen Donaugebiet - ein Korridor zwischen dem Balkan und Mitteleuropa im 6.-5. Jt. v. Chr. In W. Schier, F. Drasovean (eds.), The Neolithic and Eneolithic in Southeast Europe. New approaches to dating and cultural dynymics in the $6^{\text {th }}$ to $4^{\text {th }}$ millenium BC. Verlag Marie Leidorf GmbH. Rahden/Westf.: 347-368.

Barton A. J. 1994. Fishing for Ivory Worms: A Review of Ethnographic and Historically Recorded Dentalium Source Locations. Upublished MA thesis in Archaeology. Simon Fraser University. Burnaby.

Bar-Yosef Mayer, D. 2008. Dentalium Shells Used by Hunter-Gatherers and Pastoralists in the Levant. Archaeofauna 17: 103-110.

Bar-Yosef Mayer D., Gümüș B. A. 2010. Fossil Hunting in the Neolithic: Shells from the Taurus Mountains at Catalhöyük, Turkey. Geoarchaeology: An International Journal 25(3): 375-392.

Batović Š. 1979. Jadranska zona. In A. Benac (ed.), Praistorija jugoslavenskih zemalja II, Neolit. Akademija nauka i umjetnosti Bosne i Hercegovine. Centar za balkanološka istraživanja. Sarajevo: 473-634.

Benac A. 1971. Obre II, neolitsko naselje butmirske grupe na Gornjem polju. Glasnik Zemaljskog muzeja NS/XXVI: 5-300.

1973. Obre I - neolitsko naselje Starčevo-impreso i kakanjske kulture na Raskršću. Glasnik Zemaljskog Muzeja 27(28): 5-171.

Bronk Ramsey C. 2013. OXCal program, version 4.2. https://c14.arch.ox.ac.uk/oxcal.html

Brukner B. 1981. Zum Problem der Auflösung der Frühäneolithischen Kulturen. Archaeologia Iugoslavica 2021: $16-26$.

Brunšmid J. 1902. Nahođaji bakrenog doba iz Hrvatske i Slavonije i susjednih zemalja. Vjesnik hrvatskoga arheološkog društva VI: 32-67.

Burić M. 2009. Vinčanska kultura i njezin uticaj na neolitik istočne Hrvatske. Unpublished PhD thesis. Faculty of Philosophy. University of Zagreb. Zagreb.

2011. Gradac u Bapskoj-slika života Istočne Hrvatske prije 7000 godina, Izdanja povodom obilježavanja stogodišnjice prvih arheoloških istraživanja u Bapskoj (1911-2011). University of Zagreb. Zagreb.
2014. Bapska-Gradac. In J. Balen, T. Hršak and R. Šošić-Kindžić (eds.), Gifts of the Earth. The Neolithic between the Sava, Drava and Danube. Museum of Slavonia, Archaeological Museum and Faculty of Philosophy. Osijek, Zagreb: 9-11.

Caro 0. (1997-2011). Seashells collections. on/line: http:// www.idscaro.net/sci/01_coll/index.htm (last accessed 31 July 2016).

Chapman J. 1981. The Vinča Culture of South-East Europe. Studies in chronology, economy and society. British Archaeological Reports IS 117. Archaeopress. Oxford.

2000. Fragmentation in Archaeology. People, Places and Broken Objects in the prehistory of South-Eastern Europe. Routledge. London.

Chapman J., Gaydarska B. and Balen J. 2012 Spondylus Ornaments in the Mortuary Zone at Neolithic Vukovar on the Middle Danube. Vjesnik Arheološkog muzeja u Zagrebu 45(1): 191-210.

CLEMAM (Checklist of European Marine Molluscs) 2014. Checklist of European Marine Mollusca. Public scientific database, consulted on 29.01.2014, hosted by Muséum National d'Histoire Naturelle (M. N. H. N.). Paris. on/line: http://www.mnhn.fr/biotaxis/clemam

Comşa E. 1973. Parures néolithiques en coquillages marins découvertes en territoire roumain. Dacia N.S. 17: 61-76.

Dimitrijević S. 1968. Sopotsko-lenđelska kultura. Monographiae Archaeologicae I. Filozofski fakultet, Arheološki institut. Zagreb.

1979. Severna zona. In A. Benac (ed.), Praistorija jugoslavenskih zemalja 2. Neolit. Akademija nauka i umjetnosti Bosne i Hercegovine, Centar za balkanološka istraživanja. Sarajevo: 229-362.

Dimitrijević V., Tripković B. 2006. Spondylus and Glycymeris bracelets: trade reflections at Neolithic Vinča - Belo Brdo. Documenta Praehistorica 33: 237-252.

Dimitrijević V., Tripković B. and Jovanović G. 2010. Perle od dentalijuma - ljuštura morskih mekušaca na nalazištu Vinča - Belo Brdo. Starinar LX: 7-18.

Dimitrijević V. 2014. The provenance and use of fossil scaphopod's shells at the Late Neolithic/Eneolithic site Vinča - Belo Brdo. In K. Szabo, C. Dupont, V. Dimitrijević, L. G. Gastelum and N. Serrand (eds.), Archaeomalacology: Shells in the Archaeological Record. British Archaeological Reports IS 2666. Archaeopress. Oxford: 33-42.

Fischer W., Bauchot M.-L. and Schneider M. (ed.) 1987. Fiches FAO d'identification des espèces pour les be- 
soins de la pêche. (Révision 1). Méditerranée et mer Noire. Zone de pêche 37. Volume I. Végétaux et Invertébrés. Publication préparée par la FA0, résultat d'un accord entre la FAO et la Commission des Communautés Européennes (Projet GCP/INT/422/EEC) financée conjointement par ces deux organisations. Rome.

Georghiou D. 2012. "Skeuomorphs": on the rhetoric of material in the Gumelniţa tradition. Documenta Praehistorica 39: 287-294.

Girić M. 1971. Mokrin - nekropola ranog bronzanog doba. Smithsonian Institution, Narodni muzej, Arheološko društvo Jugoslavije. Washington, Kikinda, Beograd.

Ifantidis F. 2009. Cosmos in fragments: Spondylus and Glycymeris adornment at Neolithic Dispilio, Greece. In F. Ifantidis, M. Nikolaidou (eds.) Spondylus in Prehistory: New Data \& approaches-Contribution to the Archaeo$\log y$ of shell technology. British Archaeological Report IS 2216. Archaeopress. Oxford: 123-137.

Ignjatović M. 2008. Katalog. In D. Nikolić (ed.), Vinča, praistorijska metropola. Filozofski fakultet u Beogradu, Narodni muzej u Beogradu, Muzej grada Beograda \& Srpska akademija nauka i umetnosti. Beograd: 203-280.

Ivanov I., Avramova. M. 2000. Varna necropolis: The Dawn of European Civilization. Agatho. Sofia.

Ivanova M. 2012. Perilous Waters: Early Maritime Trade along the Western Coast of the Black Sea (Fifth Millennium). Oxford Journal of Archaeology 31(4): 339-365.

John J. 2009. Status of Spondylus artifacts within the LBK grave goods. In F. Ifantidis, M. Nikolaidou (eds.), Spondylus in Prehistory: New Data \& approaches-Contribution to the Archaeology of shell technology. British Archaeological Reports IS 2216. Archaeopress. Oxford: 39-45.

Kalicz N., Szénászky J. 2001. Spondylus-Schmuck im Neolithikum des Komitats Békés, Südostungarn. Prähistorische Zeitschrift 76(1): 24-54.

Karali L. 1999. Shells in Aegean Prehistory. British Archaeological Reports IS 761. Archaeopress. Oxford.

Karmanski S. 1977. Katalog antropomorfne i zoomorfne plastike iz okoline Odžaka. Arheološka zbirka. Odžaci.

Kukoč S. 2012. Spondylus Gaederopus u neolitičkim kulturama na istočnom Jadranu. Histria Antiqua 21: 77-202.

Leković V. 1985. The Starčevo Mortuary Practice - New Perspectives. Godišnjak XXIII, Centar za balkanološka istraživanja 21: 157-172.
Le Renard J. 1994. CLEMAM - Check List of European Marine Mollusca. http://www.somali.asso.fr/clemam/in dex.clemam.html (last accessed 31 July 2016).

Moore R. C. 1969. Treatise on invertebrate paleontology. The Geological Society of America. The University of Kansas. Lawrence.

Müller J. 1997. Neolithische und chalkolithische Spondylus-Artefakte. Anmerkungen zu Verbreitung, Tauschgebiet und sozialer Funktion. In C. Becker, M. L. Dunkelmann, C. Metzner-Nebelsick, H. Peter-Röcher, M. Roeder and B. Teržan (eds.), Xrovos. Beiträge zur prähistorischen Archäologie zwischen Nord- und Südosteuropa. Festschrift für Bernhard Hänsel. Verlag Marie Leidorf Gmbh. Espelkamp: 91-106.

Nieszery N., Breinl L. 1993. Zur Trageweise des Spondylusschmucks in der Linearbandkeramik. Archaeologisches Korrespodenzblatt 23: 427-438.

Nikolaidou M. 2003. Items of Adornment. In E. S. Elsterand, C. Renfrew (eds.), Prehistoric Sitagroi: Excavationsin Northeast Greece, 1968-1970. University of California, Cotsen Institute of Archaeology. Los Angeles: 331360 .

Oross K. and 14 co-authors. 2016. Midlife changes: the Sopot burial ground at Alsónyék. Bericht der RömischGermanischen Kommission 94: 151-178.

Osztás A., Zalai-Gaal I. and Bánffy E. 2012. Alsónyék-Bátaszék: a new chapter in the research of Lengyel culture. Documenta Praehistorica 39: 377-396.

Papathanasopoulos G. A. 1996. Catalogue. In G. A. Papathanasopoulos (ed.), Neolithic Culture in Greece. N. P. Goulandris Foundation \& Museum of Cycladic Art. Athens: 228-229.

Petrović B., Katić V. and Spasić M. 2009. Život u glini. Neolitska umetnost na tlu Beograda-figuralna plastika iz zbirki Muzeja grada Beograda. Muzej grada Beograda. Beograd.

Raczky P. 1994. Two Late Neolithic 'Hoards' from Csóka (Čoka)-Kremenyák in the Vojvodina. In G. Lốrinczy (ed.), Von der Steinzeit bis zum Mittelalter, Ottó Trogmayer Festschrift. Mora Ferenz Múseum. Szeged: 161-172.

Rajković D. 2014. Čepin-Ovčara/Tursko groblje. In J. Balen, T. Hršak and R. Šošić-Kindžić (eds.), Gifts of the Earth. The Neolithic between the Sava, Drava and Danube. Volume 2. Museum of Slavonia, Archaeological Museum and Faculty of Philosophy. Osijek, Zagreb: 22-28.

Regenye J., Biró K. and Levente F. 2009. Egy neolitikus kincslelet töredékei. In G. Ilon (ed.), MSMO $V I$. Pro- 
ceedings of the $6^{\text {th }}$ meeting for the researchers of prehistory. Raw materials and trade. Field Service for Cultural Heritage and Vas County Museums' Directorate. Budapest and Szombathely: 421-426.

Reimer P. J. and 29 coauthors. 2013. IntCal 13 and Marine 13 radiocarbon age calibration curves, $0-50,000$ years cal BP. Radiocarbon 55(4): 1869-1887.

Roglić J. 2006. Geografske regije Hrvatske i susjednih zemalja. Školska knjiga, Geografsko društvo. Zagreb.

Séfériadés M. L. 1995. Spondylus Gaderopus: The Earliest European Long Distance Exchange System. Poročilo o raziskovanju paleolitika, neolitika in eneolitika $v$ Sloveniji 22: 238-256.

Shackleton J., Elderfield H. 1990. Strontium isotope dating of the source of Neolithic European Spondylus shell artefacts. Antiquity 64: 312-315.

Shackleton N., Renfrew C. 1970. Neolithic trade routes realigned by oxygen isotope analyses. Nature 228: 10621064.

Siklósi Zs. 2004. Prestige goods in the Neolithic of the Carpathian Basin. Material manifestations of social differentiation. Acta Archaeologica Hungarica 55: 1-62.

2013. Traces of Social Inequality during the Late Neolithic in the Eastern Carpathian Basin. Dissertationes Pannonicae 4(3). Eötvös Lorand University, Institute of Archaeological Sciences. Budapest.

Sprague R. 2004. Incised Dentalium Shell Beads in the Plateau Culture Area. BEADS: Journal of the Society of Bead Researchers 16: 51-68.

Srejović D. 1969. Lepenski Vir, nova praistorijska kultura u Podunavlju. Srpska književna zadruga. Beograd.

Stanković S. 1988. Šljivik-Stragari, Trstenik. In Srejović D. (ed.), Neolithic of Serbia. Faculty of Philosophy, Center for Archaeological Research. Beograd: 95-97.

Sümegi P. 2009. Ốskori kultúrák ékszereinek elemzése lokális és távolsági anyagok a csiga és kagylóékszerek között. In G. Ilon (ed.), MSMO $\Sigma$ VI. Proceedings of the $6^{\text {th }}$ meeting for the researchers of prehistory. Raw materials and trade. Szombathely: 335-346.

Sztancs D. M., Beldiman C. 2010. Wietenberg Dentalium shell beads discovered at Cerişor - cave no. 1, Hunedoara County, Romania. Analele Universitătii Creștine "Dimitrie Cantemir", Seria Istorie-serie nouă 1(4): 76-89.

Sztáncsuj S. J. 2005. The Early Copper Age Hoard from Ariusd (Erosd). In. Gh. Dumitroaia, J. Chapman, O. Weller,
C. Preoteasa, R. Munteanu, D. Nicola, D. Monah (eds.), Cucuteni, 120 Years of Research. Time to sum up. Neamt County Museums. Piatra-Neamt, Iasi: 85-105.

Šimić J. 2006a. Čepin-0včara/Tursko groblje. Hrvatski arheološki godišnjak 2/2005: 9-10.

2006b. Sopotska nalazišta na osječkom području. In Tomaž A. (ed.), Od Sopota do Lengyela: prispevki o kamenodobnih in bakrenodobnih kulturah med Savo in Donavo. Annales Mediterranea. Koper: 39-42.

2007a. Čepin-0včara/Tursko groblje, istraživanje 2006. Obavijesti Hrvatskog arheološkog društva 39(1): 6572.

2007b. Čepin-Ovčara/ Tursko groblje. Hrvatski arheološki godišnjak 3/2006: 13-14.

2008. Hermanov vinograd - arheološko nalazište mlađeg kamenog doba u Osijeku. Exhibition catalogue. Muzej Slavonije. Osijek.

Tasić N. 2008. Nemi svedoci jednog vremena-figuralna umetnost Vinče. In D. Nikolić (ed.), Vinča, praistorijska metropola. Filozofski fakultet u Beogradu, Narodni muzej u Beogradu, Muzej grada Beograda \& Srpska akademija nauka i umetnosti. Beograd: 139-164.

Todorova H. 1995. Bemerkungen zum frühen Handelsverkehr währen des Neolithikums und des Chalkolithikums im westlichen Schwarzmeerraum. In B. Hänsel (ed.), Handel, Tausch und Verkehr im Bronze- und Früheisenzeitlichen Südosteuropa. Dr. Rudolf Habelt Gmbh. München-Berlin: 53-65.

2002. Die Mollusken in den Gräberfeldern von Durankulak. In H. Todorova (ed.), Durankulak. Die Prähistorischen Gräberfelder von Durankulak, Band II. Deutsches Archäologisches Institut. Sofia, Berlin: 177-186.

Todorova H., Vaisov I. 2001. Der kupferzeitliche Schmuck Bulgariens. Prähistorische Bronzefunde 20/6. Franz Steiner Verlag. Stuttgart.

Vasić M. 1932. Preistoriska Vinča I. Državna štamparija Kraljevine Srbije. Beograd.

1936. Preistoriska Vinča III. Državna štamparija Kraljevine Srbije. Beograd.

Vuković J., Perić S. 2014. Male figurines from PavlovacČukar, Southern Serbia. In C.-E. Ursu, S. Țerna (eds.), Anthropomorphism and symbolic behaviour in the Neolithic and Copper Age communities of South-Eastern Europe. Editura Karl A. Romstorfer. Suceava: 249-274. 
Windler A. 2013. From the Aegean Sea to the Parisian Basin. How Spondylus can rearrange our view on trade and exchange. Metalla 20(2): 87-115.

Willms C. 1985. Neolithischer Spondylusschmuck. Hundert Jahre Forschung. Germania 65(2): 331-343.
Zilhão J. 2006. Genes, Fossils, and Culture. An Overview of the Evidence for Neandertal-Modern Human Interaction and Admixture. Proceedings of the Prehistoric Society 72: $1-20$ 